\title{
Electron carriers involved in autotrophic and heterotrophic acetogenesis in the thermophilic bacterium Thermoanaerobacter kivui
}

\author{
Alexander Katsyv $^{1} \cdot$ Surbhi Jain ${ }^{1} \cdot$ Mirko Basen $^{2} \cdot$ Volker Müller $^{1}$
}

Received: 11 June 2021 / Accepted: 27 September 2021 / Published online: 14 October 2021

(c) The Author(s) 2021

\begin{abstract}
Thermoanaerobacter kivui is an acetogenic model organism that reduces $\mathrm{CO}_{2}$ with electrons derived from $\mathrm{H}_{2}$ or $\mathrm{CO}$, or from organic substrates in the Wood-Ljugdahl pathway (WLP). For the calculation of ATP yields, it is necessary to know the electron carriers involved in coupling of the oxidative and reductive parts of metabolism. Analyses of key catabolic oxidoreductases in cell-free extract (CFE) or with purified enzymes revealed the physiological electron carriers involved. The glyceraldehyde-3-phosphate dehydrogenase (GA3P-DH) assayed in CFE was NAD ${ }^{+}$-specific, $\mathrm{NADP}^{+}$was used with less than $4 \%$ and ferredoxin (Fd) was not used. The methylene-THF dehydrogenase was $\mathrm{NADP}^{+}$-specific, $\mathrm{NAD}^{+}$or Fd were not used. A Nfn-type transhydrogenase that catalyzes reduced Fd-dependent reduction of NADP ${ }^{+}$with NADH as electron donor was also identified in CFE. The electron carriers used by the potential electron-bifurcating hydrogenase (HydABC) could not be unambiguously determined in CFE for technical reasons. Therefore, the enzyme was produced homologously in T. kivui and purified by affinity chromatography. HydABC contained $33.9 \pm 4.5 \mathrm{~mol} \mathrm{Fe} / \mathrm{mol}$ of protein and FMN; it reduced $\mathrm{NADP}^{+}$but not NAD ${ }^{+}$. The methylene-THF reductase (MetFV) was also produced homologously in $T$. kivui and purified by affinity chromatography. MetFV contained $7.2 \pm 0.4 \mathrm{~mol} \mathrm{Fe} / \mathrm{mol}$ of protein and FMN; the complex did neither use NADPH nor NADH as reductant but only reduced Fd. In sum, these analysis allowed us to propose a scheme for entire electron flow and bioenergetics in T. kivui.
\end{abstract}

Keywords Acetogenic metabolism $\cdot$ Extremophile $\cdot$ Electron-bifurcating hydrogenase $\cdot$ Methylene-THF reductase

$\begin{array}{ll}\text { Abbreviations } \\ \text { THF } & \begin{array}{l}\text { Tetrahydrofolate (5,6,7,8-tetrahydropteroyl- } \\ \text { L-glutamic acid) }\end{array} \\ \text { BV } & \text { Benzyl viologen } \\ \text { MV } & \text { Methyl viologen } \\ \text { CFE } & \text { Cell-free extract } \\ \text { GA3P } & \text { Glyceraldehyde-3-phosphate } \\ \text { GA3P-DH } & \text { Glyceraldehyde-3-phosphate } \\ & \text { dehydrogenase } \\ \text { G6P } & \text { Glucose-6-phosphate } \\ \text { G6P-DH } & \text { Glucose-6-phosphate deyhdrogenase }\end{array}$

Communicated by H. Atomi.

Volker Müller

vmueller@bio.uni-frankfurt.de

1 Department of Molecular Microbiology and Bioenergetics, Institute of Molecular Biosciences, Johann Wolfgang Goethe University, Frankfurt am Main, Germany

2 Microbiology, Institute of Biological Sciences, University of Rostock, 18059 Rostock, Germany
Fd Ferredoxin

PFOR Pyruvate:ferredoxin oxidoreductase

TPP Thiamine pyrophosphate

CoA Coenzyme A

WLP Wood-Ljungdahl pathway

CODH/ACS Carbon monoxide dehydrogenase/acetylCoA synthase

CooS Monofunctional CO dehydrogenase

ATP Adenosine triphosphate

Ech Energy-converting hydrogenase

Rnf Rhodobacter nitrogen fixation

HydABC Electron-bifurcating hydrogenase

MTHFR Methylene-THF reductase

[4Fe-4S] Iron-sulfur cluster

[FeFe] Fe-Fe H-cluster

SDS Sodium dodecyl sulfate

OD Optical density

HDCR Hydrogen-dependent $\mathrm{CO}_{2}$ reductase

SEM Standard error of the mean

FMN Flavin mononucleotide 
FAD

TLC

Flavin adenine dinucleotide

Thin-layer chromatography

\section{Introduction}

Acetogenic bacteria are a polyphyletic group and characterized by an ancient pathway for carbon dioxide fixation that is coupled to energy conservation by a chemiosmotic mechanism of ATP synthesis (Drake et al. 2008). $\mathrm{CO}_{2}$ is fixed by the Wood-Ljugdahl pathway (WLP), a pathway with two branches in which the methyl and the carbonyl group of acetyl-CoA are formed from one mol of $\mathrm{CO}_{2}$ each (Ljungdahl 1986; Wood et al. 1986). The two branches converge by forming a $\mathrm{C}-\mathrm{C}$ bond, with the production of acetyl-CoA (Ragsdale and Wood 1985). In the anabolic route, acetyl$\mathrm{CoA}$ is further carboxylated to pyruvate and from here, carbon flows towards the usual biosynthetic routes for the production of cell material (Fairhurst et al. 1956; Kandler 1983). In the catabolic route, acetyl-CoA is converted to acetate via acetyl-phosphate, giving rise to one mol ATP per mol of acetate (Schaupp and Ljungdahl 1974). Since one ATP is consumed in the first step of the methyl branch (Himes and Harmony 1973), the overall ATP balance by substrate level phophorylation is zero and to gain net cellular ATP, acetogens employ a chemiosmotic mechanism for ATP synthesis in addition (Schuchmann and Müller 2014). Indeed, there are two different types of respiratory enzymes present in acetogens. Both use reduced ferredoxin $\left(\mathrm{Fd}^{2-}\right)$ as electron donor, but the electron acceptor is either $\mathrm{H}^{+}$ $\left(\mathrm{Fd}^{2-}: \mathrm{H}^{+}\right.$oxidoreductase, Ech) (Schoelmerich and Müller 2019) or $\mathrm{NAD}^{+}\left(\mathrm{Fd}^{2-}: \mathrm{NAD}^{+}\right.$oxidoreductase, Rnf) (Biegel and Müller 2010). Electron transfer from reduced $\mathrm{Fd}$ to the electron acceptor leads to transport of ions $\left(\mathrm{H}^{+}, \mathrm{Na}^{+}\right)$across the cytoplasmic membrane and the built up of a transmembrane electrochemical ion potential which in turn drives the synthesis of ATP via a membrane-integral $\mathrm{F}_{1} \mathrm{~F}_{\mathrm{O}}$ ATP synthase (Hess et al. 2013; Schoelmerich and Müller 2019; Kuhns et al. 2020). It is important to note that acetogens have either one of these two enzymes, never both, and are, therefore, classified as Rnf- or Ech-acetogens (Schuchmann and Müller 2014). $\mathrm{H}_{2}$ or NADH are the "waste" products of these respirations and are re-oxidized in the WLP (Müller 2003; Katsyv and Müller 2020). Autotrophic growth of acetogens on $\mathrm{H}_{2}+\mathrm{CO}_{2}$ with a free energy change of only $-95 \mathrm{~kJ} /$ mol under standard conditions is at the thermodynamic limit; taken into account environmental $\mathrm{H}_{2}$ concentrations (Thauer et al. 1977; Müller 2003; Schuchmann and Müller 2014), this value goes down to around $-20 \mathrm{~kJ} / \mathrm{mol}$, allowing for the synthesis of only $\approx 0.3 \mathrm{~mol} \mathrm{ATP} / \mathrm{mol}$ acetate (Müller 2003).

The critical number for the energetics of acetogens is the number of moles of reduced $\mathrm{Fd}$ available for the respiratory enzymes. This number depends on the electron carrier specificity of the enzymes of the WLP. The ultimate source of electrons is molecular hydrogen which is oxidized by electron-bifurcating hydrogenases (Schuchmann and Müller 2012; Wang et al. 2013a, b). Four moles of hydrogen are oxidized with the concomitant reduction of two moles pyridine nucleotides $(\mathrm{NAD}(\mathrm{P}) \mathrm{H})$ and two moles reduced $\mathrm{Fd}$. If more than one enzyme in the WLP requires reduced $\mathrm{Fd}$ as reductant, there would be a lack of electrons for the electron transport chain. Therefore, for the calculation of ATP yields, it is crucial to know the electron carrier specificity of the WLP enzymes in a given species.

The ability to utilize syngas $\left(\mathrm{CO}_{2}, \mathrm{CO}, \mathrm{H}_{2}\right)$ makes acetogenic bacteria to key players in the global carbon and hydrogen cycle and thus prime candidates as driving forces in a $\mathrm{H}_{2}$ - and $\mathrm{CO}_{2}$-bioeconomy (Müller 2019). In the last years, tremendous progress was made in developing acetogens by metabolic engineering to convert syngas to biofuels (Daniell et al. 2012; Liew et al. 2016; Köpke and Simpson 2020) or establishing acetogens for $\mathrm{H}_{2}$ capture and storage in the biohydrogen economy (Schwarz et al. 2020, 2021; Müller 2019). However, the energetics of product formation from $\mathrm{H}_{2}+\mathrm{CO}_{2}$ and $\mathrm{CO}$ are only poorly understood in most acetogens (Katsyv and Müller 2020).

The thermophilic acetogen Thermoanaerobacter kivui grows in mineral media with high growth rates on $\mathrm{H}_{2}+\mathrm{CO}_{2}$, $\mathrm{CO}$ or mixtures of both (synthesis gas, syngas) (Leigh et al. 1981; Klemps et al. 1987; Hess et al. 2014; Weghoff and Müller 2016; Basen and Müller 2017). It contains the Ech complex as respiratory enzyme (Schoelmerich and Müller 2019), a $\mathrm{H}_{2}$-dependent $\mathrm{CO}_{2}$ reductase (HDCR) (Schwarz et al. 2018) as first enzyme in the carbonyl branch, a pyruvate:ferredoxin oxidoreductase (PFOR) (Katsyv et al. 2021) and a $\mathrm{Fd}^{2-}$-dependent $\mathrm{CO}$ dehydrogenase (Jain et al. 2021) (Table 1). Unforunately, the electron carrier specificity of the other redox enzymes of the WLP are unknown. Here, we have identified the electron carriers involved in these reactions, using cell-free extract (CFE) or purified proteins as experimental material. These studies allowed us to present the first nearly complete pathway of electron flow and the bioenergetics in this model acetogen.

\section{Materials and methods}

\section{Growth of T. kivui}

T. kivui (DSM 2030) was grown at $66^{\circ} \mathrm{C}$ in complex medium under anoxic conditions in 1-1-bottles (Glasgerätebau Ochs, Bovenden-Lenglern, Germany) using $28 \mathrm{mM}$ D-glucose as substrate (Weghoff and Müller 2016). The medium was prepared using the anaerobic techniques described previously (Hungate 1969; Bryant 1972). Growth was monitored by 
Table 1 Specific activities of purified oxidoreductases involved in carbon catabolism, carbon fixation and energy metabolism of T. kivui

\begin{tabular}{|c|c|c|}
\hline Enzyme & Substrates & Specific activity $[\mathrm{U} / \mathrm{mg}]$ \\
\hline Pyruvate:ferredoxin oxidoreductase (PFOR) ${ }^{1}$ & Pyruvate $+\mathrm{CoA}+\mathbf{F d}$ & $27.2 \pm 4.1$ \\
\hline Carbon monoxide dehydrogenase (CODH/ACS $)^{2}$ & $\mathrm{CO}+\mathbf{F d}$ & $111.5 \pm 15.4$ \\
\hline Carbon monoxide dehydrogenase $(\mathrm{CooS})^{2}$ & $\mathrm{CO}+\mathbf{F d}$ & $0.5 \pm 0.03$ \\
\hline $\mathrm{H}_{2}$-dependent $\mathrm{CO}_{2}$ reductase $(\mathrm{HDCR})^{3}$ & $\begin{array}{l}\mathrm{H}_{2}+\mathrm{CO}_{2} \rightarrow \mathrm{H}^{+}+\text {formate } \\
\text { Formate }+\mathrm{H}^{+} \rightarrow \mathrm{CO}_{2}+\mathbf{H}_{2}\end{array}$ & $\begin{array}{l}930 \\
900\end{array}$ \\
\hline Energy-converting Hydrogenase (Ech) ${ }^{4}$ & $\begin{array}{l}\mathrm{H}_{2}+\mathbf{F d} \\
{ }^{\%} \mathrm{Fd}^{2-}+\mathrm{H}^{+} \rightarrow \mathbf{H}_{2}\end{array}$ & $\begin{array}{l}1.2 \pm 0.2 \\
10.2 \pm 3.4\end{array}$ \\
\hline
\end{tabular}

Substrates or products whose reduction, oxidation, or formation were monitored are presented in bold. The activities were determined at $66{ }^{\circ} \mathrm{C}$ with purified proteins. One unit (U) equals $2 \mu \mathrm{mol}$ of electrons transferred per min. All measurements were performed in biological replicates. Fd, ferredoxin (isolated from $C$. pasteurianum)

${ }^{\%} \mathrm{Fd}^{2-}$-regenerating system (Fd, TPP, CoA, pyruvate, PFOR (Katsyv et al. 2021))

${ }^{1}$ purified and characterized in Katsyv et al. (2021)

${ }^{2}$ purified and characterized in Jain et al. (2021)

${ }^{3}$ purified and characterized in Schwarz et al. (2018)

${ }^{4}$ unpublished data measuring the $\mathrm{OD}$ at $600 \mathrm{~nm}$. Plating and cultivation on solid media were the same as described previously (Basen et al. 2018). $200 \mu \mathrm{g} / \mathrm{ml}$ kanamycin was used to select for recombinants.

\section{Preparation of CFE}

All buffers used were prepared using the anaerobic techniques described previously (Hungate 1969; Bryant 1972). All purification steps were performed under strictly anaerobic conditions at room temperature in an anaerobic chamber (Coy Laboratory Products, Grass Lake, Michigan, USA) filled with $95-98 \% \mathrm{~N}_{2}$ and 2-5\% $\mathrm{H}_{2}$. Cells of $T$. kivui were harvested and washed twice in buffer A1 $(50 \mathrm{mM}$ Tris/ $\mathrm{HCl}$, $10 \mathrm{mM} \mathrm{NaCl}, 20 \mathrm{mM} \mathrm{MgSO}_{4}, 2 \mathrm{mM}$ DTE, $4 \mu \mathrm{M}$ resazurin, $20 \%$ [v/v] glycerol, $\mathrm{pH} 7.5)$. The cells were resuspended in $20 \mathrm{ml}$ buffer A1 including $0.5 \mathrm{mM} \mathrm{PMSF}$ and $0.1 \mathrm{mg} /$ $\mathrm{ml}$ DNAseI and passed one time through a French pressure cell (110 MPa). Cell debris was removed by centrifugation at $24,000 \times g, 4{ }^{\circ} \mathrm{C}$ for $20 \mathrm{~min}$. The supernatant contained the $\mathrm{CFE}$, which was stored at $4{ }^{\circ} \mathrm{C}$ for further investigations.

\section{Cloning of pMU131_His-hydABC and pMU131_ His-metFV}

Plasmid pMU131_His-hydABC and pMU131_His$m e t F V$ were used for the expression of hydABC (TKV c19580-TKV_c19600) and metFV (TKV_c19880-TKV_ c19890) in T. kivui. The plasmids are based on plasmid pMU131 (Shaw et al. 2010), that replicates in T. kivui and confers resistance to kanamycin (Basen et al. 2018; Katsyv et al. 2021). The inserts hydABC (4219 bp) and His-metFV (1612 bp) were amplified using the primers HydABCTK_ for (3) and HydABCTK_rev (4) or His-MetFVTK_for
(5) and His-MetFVTK_rev (6). The backbone $p M U 131$ (7192 bp) was amplified using the primers pMU131_for (1) and pMU131_rev (2), followed by the fusion of the PCR products via Gibson Assembly (Gibson Assembly Mastermix, NEB, Frankfurt/Main, Germany). A DNA sequence encoding a $10 \times$ histidine-tag (His-tag) was introduced in pMU131_hydABC at the 3'-end of the gene hydA using corresponding primers His-HydA_for (9) and His-HydA_rev (10). T. kivui (DSM 2030) was transformed with the resulting plasmids pMU131_His-hydABC and pMU131_His$m e t F V$ as described previously (Basen et al. 2018). Cells were plated on agar medium containing $28 \mathrm{mM}$ glucose as carbon source and $200 \mu \mathrm{g} / \mathrm{ml}$ kanamycin. To verify the transformation, colonies were picked and the transformed plasmids were checked using primer pairs seq1_for (7)/seq2_rev (8) binding on the $p M U 131$ backbone and amplifying the complete His-hydABC or His-metFV locus (Fig. S1).

\section{Production and purification of His-HydABC and His-MetFV}

T. kivui pMU131_His-hydABC or pMU131_His-metFV cells were grown as described. All purification steps were performed under strictly anoxic conditions at room temperature in an anoxic chamber (Coy Laboratory Products, Grass Lake, Michigan, USA) filled with $95-98 \% \mathrm{~N}_{2}$ and $2-5 \% \mathrm{H}_{2}$. Cells were harvested and washed twice in buffer A2 $\left(50 \mathrm{mM}\right.$ Tris/ $\mathrm{HCl}, 150 \mathrm{mM} \mathrm{NaCl}, 20 \mathrm{mM} \mathrm{MgSO}{ }_{4}$, $10 \mathrm{mM}$ imidazole, $0.5 \mathrm{mM}$ DTE, $4 \mu \mathrm{M}$ resazurin, $20 \%$ [v/v] glycerol, $\mathrm{pH}$ 7.5). All buffers additionally contained $10 \mu \mathrm{M}$ FMN to avoid the loss of flavin during purification, if not otherwise specified. The cells were resuspended in $20 \mathrm{ml}$ buffer A2 including $0.5 \mathrm{mM}$ PMSF and $0.1 \mathrm{mg} / \mathrm{ml}$ DNAseI and passed one time through a French pressure 
cell (110 MPa). Cell debris was removed by centrifugation at $24,000 \times g$ for $20 \mathrm{~min}$. Purification of the His-tagged proteins was carried out with a nickel nitrilotriacetic acid $\left(\mathrm{Ni}^{2+}\right.$-NTA) resin (Qiagen, Hilden, Germany) using a gravity flow column under anoxic conditions as described previously (Katsyv et al. 2021). Fractions containing HisHydABC or His-MetFV were collected, pooled, concentrated, using 50-kDa VIVASPIN tubes, and separated on a superdex 200 10/300 GL increase prepacked column (GE Healthcare Life Sciences, Little Chalfont, UK). The sample was loaded on a superdex 200 column equilibrated with buffer B (50 mM Tris/HCl, $150 \mathrm{mM} \mathrm{NaCl}, 20 \mathrm{mM} \mathrm{MgSO}_{4}$, $2 \mathrm{mM}$ DTE, $4 \mu \mathrm{M}$ resazurin, 20\% [v/v] glycerol, $\mathrm{pH} 7.5$ ) and eluted at a flow rate of $0.5 \mathrm{ml} / \mathrm{min}$. HydABC or MetFV activity eluted in a single peak with a maximum at 10.2 or $11.8 \mathrm{ml}$ elution volume. Fractions containing His-HydABC or His-MetFV were pooled and stored at $4{ }^{\circ} \mathrm{C}$.

\section{Enzyme activity assays}

All enzyme assays, unless otherwise specified, were performed in $1.8 \mathrm{ml}$ anoxic cuvettes (Glasgerätebau Ochs $\mathrm{GmbH}$, Bovenden-Lenglern, Germany) sealed by rubber stoppers in a $\mathrm{N}_{2}$ atmosphere $\left(1 \times 10^{5} \mathrm{~Pa}\right)$ at $66^{\circ} \mathrm{C}$ at an overall liquid volume of $1 \mathrm{ml}$. One unit is defined as transfer of $2 \mu \mathrm{mol}$ electrons/min. All measurements were performed in biological replicates. $\mathrm{NAD}(\mathrm{P})^{+} / \mathrm{NAD}(\mathrm{P})$ $\mathrm{H}$ was monitored spectrophotometrically at $340 \mathrm{~nm}$ $\left(\varepsilon=6.3 \mathrm{mM}^{-1} \mathrm{~cm}^{-1}\right)$, ferredoxin (Fd) (isolated from Clostridium pasteurianum (Schönheit et al. 1978)) at $430 \mathrm{~nm}\left(\varepsilon=13.1 \mathrm{mM}^{-1} \mathrm{~cm}^{-1}\right)$ and methyl viologen (MV) or benzyl viologen (BV) at $600 \mathrm{~nm}\left(\varepsilon=13.9 \mathrm{mM}^{-1} \mathrm{~cm}^{-1}\right.$ or $\varepsilon=12 \mathrm{mM}^{-1} \mathrm{~cm}^{-1}$ ).

\section{Glyceraldehyde-3-phosphate dehydrogenase}

Glyceraldehyde-3-phosphate dehydrogenase (GA3P$\mathrm{DH})$ activity was measured in buffer $\mathrm{C}(50 \mathrm{mM}$ Tris/ $\mathrm{HCl}$, $10 \mathrm{mM} \mathrm{NaCl}, 2 \mathrm{mM}$ DTE, $\mathrm{pH}$ 7.5), containing 200-500 $\mu \mathrm{g}$ CFE of glucose-grown cells, $5 \mathrm{mM}$ arsenate and $4 \mathrm{mM}$ $\mathrm{NAD}^{+} / \mathrm{NADP}^{+}$or $30 \mu \mathrm{M}$ Fd. The reaction was started by addition of $1 \mathrm{mM}$ glyceraldehyde-3-phosphate (GA3P).

\section{Methylene-THF dehydrogenase}

Methylene-THF dehydrogenase activity was measured in buffer C. The assay contained 200-500 $\mu \mathrm{g}$ CFE of glucosegrown cells, $1.5 \mathrm{mM}$ formaldehyde and $0.5 \mathrm{mM}$ tetrahydrofolate (THF). Formaldehyde reacts spontaneously, nonenzymatically with THF to yield methylene-THF (Kallen and Jencks 1966). The reaction was started by addition of $1 \mathrm{mM} \mathrm{NAD}^{+} / \mathrm{NADP}^{+}$or $30 \mu \mathrm{M} \mathrm{Fd}$.

\section{Transhydrogenase}

Transhydrogenase activity was measured in buffer $\mathrm{C}$. The assay contained $410 \mu \mathrm{g}$ CFE of glucose-grown cells and $30 \mu \mathrm{M}$ Fd. To keep the level of NADPH constant, $0.1 \mathrm{mM} \mathrm{NADP}^{+}$ were pre-reduced with 1 unit glucose-6-phosphate dehydrogenase (G6P-DH) and $20 \mathrm{mM}$ glucose-6-phosphate (G6P; $\mathrm{NADP}^{+}$reducing system) as reported previously (Kremp et al. 2020). The reaction was started by addition of $1 \mathrm{mM} \mathrm{NAD}{ }^{+}$.

\section{Electron-bifurcating hydrogenase}

The activity was measured in buffer D (50 mM EPPS, $10 \mathrm{mM}$ $\mathrm{NaCl}, \mathrm{pH} 8$ ), containing 60-100 $\mu \mathrm{g}$ CFE of glucose-grown cells or 5-10 $\mu$ g purified His-HydABC, $30 \mu \mathrm{M} \mathrm{Fd}$ and $5 \mu \mathrm{M}$ FMN; the gas phase was $100 \% \mathrm{H}_{2}\left(2 \times 10^{5} \mathrm{~Pa}\right)$. The reaction was started by addition of $4 \mathrm{mM} \mathrm{NADP}^{+} / \mathrm{NAD}^{+}$. The controls omitted either $\mathrm{Fd}$ or $\mathrm{NADP}^{+} / \mathrm{NAD}^{+} . \mathrm{H}_{2}$ evolution was assayed in 7.2-ml glass vials (Glasgerätebau Ochs $\mathrm{GmbH}$, Bovenden-Lenglern, Germany) with 5-20 $\mu$ g His-HydABC, $30 \mu \mathrm{M} \mathrm{Fd}, 5 \mu \mathrm{M}$ FMN and $10 \mathrm{mM}$ $\mathrm{NADPH} / \mathrm{NADH}$. To reduce $\mathrm{Fd}$, the assay additionally contained $5 \mu \mathrm{g}$ PFOR (isolated from T. kivui (Katsyv et al. 2021)), $400 \mu \mathrm{M}$ coenzyme $\mathrm{A}(\mathrm{CoA})$ and $100 \mu \mathrm{M}$ thiamine pyrophosphate (TPP). The reaction was started by addition of pyruvate at a final concentration of $10 \mathrm{mM} . \mathrm{H}_{2}$ was measured via gas chromatography as discribed previously (Schoelmerich and Müller 2019). The controls omitted either Fd or NADPH/NADH. To determine $\mathrm{H}_{2}$ :MV oxidoreductase activity, the assay contained $0.5-20 \mu \mathrm{g}$ purified His-HydABC or proteins from different purifications steps. The gas phase was $100 \% \mathrm{H}_{2}\left(2 \times 10^{5} \mathrm{~Pa}\right)$. The reaction was started by addition of $10 \mathrm{mM}$ MV. The effect of $\mathrm{CO}$ on the $\mathrm{H}_{2}: \mathrm{MV}$ oxidoreductase activity of His-HydABC was measured with $\mathrm{CO}$ concentrations (in the aqueous phase) ranged between $0-187 \mu \mathrm{M}$, respectively. For $K_{\mathrm{m}}$ determination, the $\mathrm{H}_{2}, \mathrm{NADP}^{+}$ and $\mathrm{Fd}$ concentrations ranged between $0-325 \mu \mathrm{M}, 0-4 \mathrm{mM}$ and $0-200 \mu \mathrm{M}$, respectively. For the determination of the $\mathrm{pH}$ and temperature profile, the assay containing His-HydABC was preincubated for $10 \mathrm{~min}$ at the $\mathrm{pH}$ or temperature indicated. The $\mathrm{pH}$ optima were determined in buffer E containing $50 \mathrm{mM}$ MES, $50 \mathrm{mM}$ CHES, $50 \mathrm{mM}$ CAPS, $50 \mathrm{mM}$ Bis-Tris, $50 \mathrm{mM}$ Tris, $10 \mathrm{mM} \mathrm{NaCl}, 4 \mathrm{mM}$ DTE, $4 \mu \mathrm{M}$ resazurin at $\mathrm{pH} 5-10$, as specified in the experiments.

\section{Methylene-THF reductase}

Methylene-THF reductase (MTHFR) activity was measured in buffer $\mathrm{F}\left(50 \mathrm{mM} \mathrm{KP}_{\mathrm{i}}, 20 \mathrm{mM}\right.$ ascorbate, $\left.\mathrm{pH} 7\right)$. The $\mathrm{MV}^{2-}$ :methylene-THF oxidoreductase assay contained $0.5 \mathrm{mM}$ THF, $1.5 \mathrm{mM}$ formaldehyde and $10 \mathrm{mM}$ MV. To reduce MV, $5 \mathrm{mM}$ sodium dithionite was added. The reaction 
was started by addition of $200 \mu \mathrm{g}$ CFE, $2-5 \mu \mathrm{g}$ His-MetFV or $10 \mu \mathrm{g}$ proteins from different purifications steps. To determine $\mathrm{Fd}^{2-}$ :methylene-THF oxidoreductase activity the assay contained $30 \mu \mathrm{g}$ His-MetFV, $0.5 \mathrm{mM}$ THF and $1.5 \mathrm{mM}$ formaldehyde. To reduce $\mathrm{Fd}$, the assay additionally contained $5 \mu \mathrm{g}$ PFOR, $400 \mu \mathrm{M}$ $\mathrm{CoA}$ and $100 \mu \mathrm{M}$ TPP. The reaction was started by addition of 10 $\mathrm{mM}$ pyruvate. In the controls, either Fd or methylene-THF was omitted. Methyl-THF was determined via HPLC as described recently (Dietrich et al. 2021). To determine methyl-THF:NAD ${ }^{+}$/ $\mathrm{NADP}^{+} / \mathrm{Fd} / \mathrm{BV}$ oxidoreductase the assay contained $400 \mu \mathrm{g} \mathrm{CFE}$ or $15-30 \mu \mathrm{g}$ His-MetFV and $4 \mathrm{mM} \mathrm{NAD}^{+} / \mathrm{NADP}^{+}, 30 \mu \mathrm{M} \mathrm{Fd}$ or $10 \mathrm{mM}$ BV. The reaction was started by addition of $1 \mathrm{mM}$ methyl-THF. To determine NADH/NADPH:methylene-THF oxidoreductase, the assay contained $400 \mu \mathrm{g}$ CFE or $20 \mu \mathrm{g}$ HisMetFV, $1.5 \mathrm{mM}$ formaldehyde and $0.5 \mathrm{mM}$ THF. The reaction was started by addition of $0.5 \mathrm{mM}$ NADH/NADPH. To determine the Fd-dependent NADH/NADPH:methylene-THF oxidoreductase activity the assay contained $20 \mu \mathrm{g}$ His-MetFV or $400 \mu \mathrm{g}$ CFE, $0.5 \mathrm{mM}$ THF, $0.5 \mathrm{mM}$ NADH/NADPH and $30 \mu \mathrm{M} F d$. The reaction was started by addition of $1.5 \mathrm{mM}$ formaldehyde. To determine the NADH/NADPH:BV oxidoreductase activity, the assay contained $30 \mu \mathrm{g}$ His-MetFV and $0.5 \mathrm{mM}$ $\mathrm{NADH} / \mathrm{NADPH}$. The reaction was started by addition of $10 \mathrm{mM}$ BV. For the determination of the $\mathrm{pH}$ and temperature profile, the assay containing His-MetFV was preincubated for $10 \mathrm{~min}$ at the $\mathrm{pH}$ or temperature indicated. The $\mathrm{pH}$ optima were determined in buffer E containing $50 \mathrm{mM}$ MES, $50 \mathrm{mM} \mathrm{CHES,} 50 \mathrm{mM}$ CAPS, $50 \mathrm{mM}$ Bis-Tris, $50 \mathrm{mM}$ Tris, $10 \mathrm{mM} \mathrm{NaCl}, 4 \mathrm{mM}$ DTE, $4 \mu \mathrm{M}$ resazurin at $\mathrm{pH} 5-10$, as specified in the experiments.

\section{Analytical methods}

The concentration of proteins was measured according to Bradford (1976). Proteins were separated in $12 \%$ polyacrylamide gels and stained with Coomassie brilliant blue G250. The iron content of the purified enzymes was determined by colorimetric methods (Fish 1988), flavin was analyzed by thin-layer chromatography (TLC) (Bertsch et al. 2013). The molecular mass of the purified His-HydABC and His-MetFV was determined using a calibrated superdex 200 column and defined size standards (ovalbumin: $43 \mathrm{kDa}$; albumin: $158 \mathrm{kDa}$; catalase: $232 \mathrm{kDa}$; ferritin: $440 \mathrm{kDa}$ ).

\section{Results and discussion}

\section{Electron carrier specificity of catabolic oxidoreductases examined in CFE of glucose-grown cells}

To analyze the electron carrier specificity of the glycolytic enzyme GA3P-DH, oxidation of GA3P by CFE of glucose-grown cells was analyzed. The CFE of $T$. kivui catalyzed GA3P oxidation coupled to $\mathrm{NAD}^{+}$reduction with an activity of $0.85 \pm 0.15 \mathrm{U} / \mathrm{mg}$ (Fig. S2A). In contrast, $\mathrm{NADP}^{+}$was reduced with very low rates $(<0.03 \mathrm{U} /$ mg) (Fig. S2B) and Fd did not serve as electron acceptor (Fig. S2C), demonstrating that $\mathrm{NAD}^{+}$is the cofactor used by the GA3P-DH.

The CFE also catalyzed the reduction of $\mathrm{NADP}^{+}$with methylene-THF as electron donor $(24.4 \pm 1.2 \mathrm{U} / \mathrm{mg}$ ) (Fig. S3A). NAD ${ }^{+}$(Fig. S3B) or Fd (Fig. S3C) were not reduced, demonstrating a NADPH-dependent methylene-THF dehydrogenase. The MTHFR of T. kivui is of the MetFV-type (metF, TKV_c19880 and metV, TKV_c19890) (Hess et al. 2014; Öppinger et al. 2021). Methylene-THF was not reduced with NADPH or NADH as reductant in CFE. The reverse reaction, oxidation of methyl-THF was not coupled to $\mathrm{NAD}^{+}, \mathrm{NADP}^{+}$or $\mathrm{Fd}$ reduction, but only to $\mathrm{BV}$ reduction $(2.4 \pm 0.7 \mathrm{U} / \mathrm{mg})$. Electron bifurcation (Fd-dependent NADH/NADPH:methylene-THF oxidoreductase) was also not observed.

The genome of T. kivui codes for an electron-bifurcating, Fd-dependent transhydrogenase, NfnAB (TKV c22270-TKV_c22280) to transfer electrons between $\mathrm{NAD}^{+}$and $\mathrm{NADP}^{+}$(Hess et al. 2014). CFE of T. kivui catalyzed the reduction of $\mathrm{NAD}^{+}$with $\mathrm{NADPH}$ only in the presence of Fd. The NAD ${ }^{+}$-dependent NADPH:Fd oxidoreductase activity was $0.04 \pm 0.01 \mathrm{U} / \mathrm{mg}$ (Fig. S4A). When Fd (Fig. S4B) or NADPH (Fig. S4C) was omitted, no $\mathrm{NAD}^{+}$reduction was observed, indicating a functional NfnAB complex. All oxidoreductase activities measured in CFEs of glucose-grown T. kivui cells are summarized in Table 2.

\section{Identification of a NADP ${ }^{+}$-dependent $\mathrm{H}_{2}: \mathrm{Fd}$ oxidoreductase activity in T. kivui and purification of the electron-bifurcating hydrogenase}

The genome of $T$. kivui encodes an electron-bifurcating hydrogenase HydABC ( hydC, hydB, hydA; TKV_ c19580-c19600 cluster) (Hess et al. 2014), which is very similar to the $\mathrm{NAD}^{+}$-dependent $\mathrm{H}_{2}: \mathrm{Fd}$ hydrogenase HydABC of Acetobacterium woodii (HydC: $44 \%$, HydB: 58\%, HydA: 48\%; Awo_c27010-c26970 cluster) (Schuchmann and Müller 2012) and Moorella thermoacetica (HydC: 49\%, HydB: 57\%, HydA: 56\%; MOTHA_18110-18090 cluster) (Wang et al. 2013a, b) or to the $\mathrm{NADP}^{+}$-dependent $\mathrm{H}_{2}: \mathrm{Fd}$ hydrogenase of Clostridium autoethanogenum (HydC: 47\%, HydB: 59\%, HydA: 54\%; CAETHG_3571-3569 cluster) (Wang et al. 2013a, b) and Clostridium ljungdahlii (HydC: 45\%, HydB: $55 \%$, HydA: 53\%; CLJU_c14720-14,700 cluster) (Nagarajan et al. 2013; Wang et al. 2013a, b). When testing for $\mathrm{NAD}^{+}$-dependent $\mathrm{H}_{2}: \mathrm{Fd}$ oxidoreductase activity in CFE 
Table 2 Oxidoreductase activities in CFE of glucose-grown T. kivui strain

\begin{tabular}{|c|c|c|}
\hline Enzyme & Substrates & $\begin{array}{l}\text { Specific } \\
\text { activity [U/ } \\
\text { mg] }\end{array}$ \\
\hline \multirow{3}{*}{$\begin{array}{l}\text { Methylene-THF dehydro- } \\
\text { genase }\end{array}$} & Methylene-THF + NADP ${ }^{+}$ & $24.4 \pm 1.2$ \\
\hline & Methylene-THF + NAD ${ }^{+}$ & $<0.005$ \\
\hline & Methylene-THF + Fd & $<0.001$ \\
\hline \multirow{4}{*}{$\begin{array}{l}\mathrm{NAD}^{+} \text {-dependent } \\
\text { NADPH:Fd oxidoreduc- } \\
\text { tase }(\mathrm{Nfn})\end{array}$} & ${ }^{\#} \mathrm{NADPH}+\mathrm{NAD}^{+}+\mathbf{F d}$ & $0.04 \pm 0.01$ \\
\hline & ${ }^{\#} \mathrm{NADPH}+\mathbf{N A D}^{+}$ & $<0.001$ \\
\hline & NADH + NADP ${ }^{+}$ & $<0.002$ \\
\hline & ${ }^{\#} \mathrm{NADPH}+\mathbf{F d}$ & $<0.001$ \\
\hline \multirow{3}{*}{$\begin{array}{l}\text { Glyceraldehyde-3-phos- } \\
\text { phate dehydrogenase } \\
\text { (GA3P-DH) }\end{array}$} & GA3P + NADP ${ }^{+}$ & $<0.03$ \\
\hline & GA3P $+\mathbf{N A D}^{+}$ & $0.85 \pm 0.15$ \\
\hline & $\mathrm{GA} 3 \mathrm{P}+\mathbf{F d}$ & $<0.001$ \\
\hline
\end{tabular}

Substrates whose reduction, oxidation, or formation were monitored are presented in bold. The activities were determined at $66^{\circ} \mathrm{C}$. One unit (U) equals $2 \mu \mathrm{mol}$ of electrons transferred per min. All measurements were performed in biological replicates. For more details see Materials and methods

Fd, ferredoxin (isolated from C. pasteurianum); THF, tetrahydrofolate ${ }^{\#}$ NADPH-regenerating system $\left(\mathrm{NADP}^{+}\right.$, G6P, G6P-DH (Kremp et al. 2020)

of T. kivui, $\mathrm{Fd}$ and $\mathrm{NAD}^{+}$reduction with $\mathrm{H}_{2}$ as reductant was only weak $(0.02 \pm 0.01 \mathrm{U} / \mathrm{mg})$. Suprisingly, NADP ${ }^{+}$ reduction with $\mathrm{H}_{2}$ as electron donor in the presence of Fd was stronger $(0.05 \pm 0.02 \mathrm{U} / \mathrm{mg})$. However, Fd reduction was also measurable with $\mathrm{H}_{2}$ as electron donor alone, indicating interference with other enzymes in the CFE. To determine the cofactor specificity of the isolated HydABC hydrogenase of T. kivui, we took advantage of a plasmid-based production system in T. kivui (Katsyv et al. 2021) to produce and purify the enzyme. Therefore, we cloned hydABC together with a DNA sequence coding for a $10 \times$ His-tag into $p M U 131$ (Fig. S5A-D). Naturally competent cells of $T$. kivui were transformed with the plasmid (Fig. S1A, B), grown on glucose and CFE was prepared. The complex was purified via a genetically engineered His-tag at HydA to apparent homogeneity by $\mathrm{Ni}^{2+}$-NTA-sepharose followed by size exclusion chromatography on Superdex 200. Using this procedure, the enzyme was purified 424-fold to apparent homogeneity with an average specific $\mathrm{H}_{2}$ :MV oxidoreductase activity of $7596.0 \pm 2370.3 \mathrm{U} / \mathrm{mg}$ and a yield of $3.2 \mathrm{mg}$ (per $2 \mathrm{~g}$ wet cells) (Table 3 ). Analyses of the purified HisHydABC separated on a $12 \%$ SDS-polyacrylamide gel revealed three proteins with apparent molecular masses
Table 3 Purification of His-HydABC from T. kivui

\begin{tabular}{lllll}
\hline Purification step & Protein [mg] & $\begin{array}{l}\text { HydABC } \\
\text { activity* [U/ } \\
\text { mg] }\end{array}$ & $\begin{array}{l}\text { Purifi- } \\
\text { cation } \\
\text { [-fold] }\end{array}$ & Yield [\%] \\
\hline $\mathrm{CFE}$ & 378.4 & 17.9 & 1 & 100 \\
$\mathrm{Ni}^{2+}$-NTA & 4.2 & 6681.2 & 373.3 & 1.1 \\
Superdex 200 & 3.2 & 7596.0 & 424.4 & 0.8 \\
\hline
\end{tabular}

${ }^{*} \mathrm{Hyd} \mathrm{ABC}$ activity was measured with $\mathrm{H}_{2}$ as electron donor and MV as electron acceptor

of $\approx 65,70$ and $\approx 18 \mathrm{kDa}$ (Fig. $1 \mathrm{~A})$. These molecular masses correspond well with the expected sizes for HydA (TKV_c19600, 64 kDa), HydB (TKV_c19590, 68 kDa) and HydC (TKV_c19580, $18 \mathrm{kDa})$ of T. kivui. Analytical size exclusion chromatography revealed a molecular mass of $348 \mathrm{kDa}$ for the purified complex, which is consistent with HydABC being a dimer. We measured $33.9 \pm 4.5 \mathrm{~mol}$ of iron/mol of protein, which matches the prediction that HydABC contains seven [4Fe-4S] cluster, three [2Fe-2S] and one $[\mathrm{FeFe}]$ cluster. All current characterized bifurcating enzymes possess either a quinone or flavin group with special redox properties (Müller et al. 2018). From bioinformatic analyses, HydABC should contain one flavin, but the nature of the flavin remained to be established. After precipitation of the purified complex and subsequent separation of the flavin-containing supernatant by thin-layer chromatography (TLC), no FAD, but FMN was detected (Fig. S6A).

The purified complex catalyzed electron bifurcation from $\mathrm{H}_{2}$ to $\mathrm{Fd}$ and $\mathrm{NADP}^{+}$with an activity of $20.8 \pm 2.5$ U/mg (Fig. 2A). When NADP ${ }^{+}$was replaced with $\mathrm{NAD}^{+}$ no activity was measurable $(<0.005 \mathrm{U} / \mathrm{mg})$, which is contrary to previous assumptions (Basen and Müller 2017; Jain et al. 2020; Hess et al. 2014; Moon et al. 2020; Weghoff and Müller 2016). Furthermore, $\mathrm{H}_{2}: \mathrm{Fd}$ oxidoreductase activity was not detectable in the absence of $\mathrm{NADP}^{+}$, demonstrating that reduction of one electron acceptor $\left(\mathrm{NADP}^{+}\right)$was strictly dependent on the presence of the other electron acceptor (Fd). When both electron acceptors were present, they were reduced simultaneously with a 1:1 stoichiometry (slope: 0.9, Fig. 2C). FMN stimulated the HydABC activity, as described also for the purified HydABC complex of A. woodii (Schuchmann and Müller 2012). Purified HisHydABC exhibited a NADP ${ }^{+}$-dependent $\mathrm{H}_{2}: \mathrm{Fd}$ oxidoreductase activity of $15.6 \pm 1.5 \mathrm{U} / \mathrm{mg}$ when FMN was omitted from the enzyme assay as opposed to $20.8 \pm 2.5 \mathrm{U} / \mathrm{mg}$ with $5 \mu \mathrm{M}$ FMN in the assay. It is important to note here, that FMN was also ommitted from buffer B during the last purification step to ensure no external FMN in the assay. The purified complex also catalyzed the reverse reaction, reduction of $\mathrm{H}^{+}$with NADPH and reduced $\mathrm{Fd}$ as electron donors with an average specific activity of $9.3 \pm 2.0 \mathrm{U} / \mathrm{mg}$ 


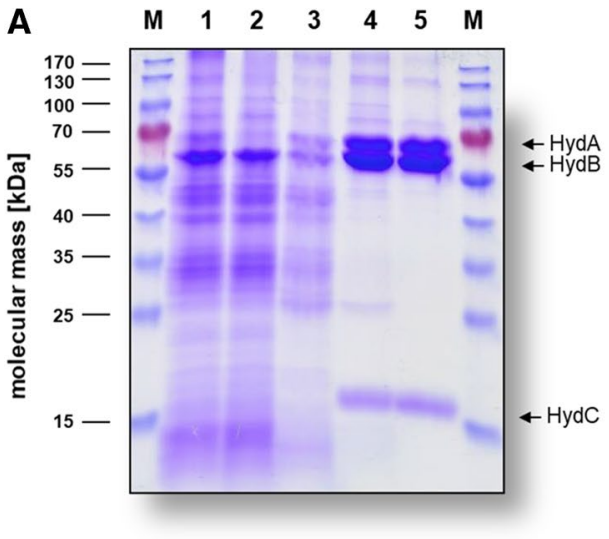

Fig. 1 SDS-PAGE monitoring the purification process of HisHydABC and His-MetFV. Samples of the different purification steps of His-HydABC (A) and His-MetFV (B) were separated by SDSPAGE (12\%) and proteins were stained with Coomassie Brilliant

(Fig. 2B). All activities of His-HydABC are summarized in Table 4. Because T. kivui is able to convert $\mathrm{CO}$ as sole carbon and energy source, we analyzed whether the bifurcating hydrogenase is inhibited by $\mathrm{CO}$. Therefore, we tested $\mathrm{H}_{2}: \mathrm{MV}$ oxidoreductase activity in the presence of different $\mathrm{CO}$ concentrations (Fig. 2D). Indeed, the enzyme was inhibited by $\mathrm{CO}$ and $50 \%$ inhibition was observed with $5.7 \pm 1.2 \mu \mathrm{M} \mathrm{CO}$ (soluble in water), indicating a strong inhibition by low $\mathrm{CO}$ concentrations in vitro.

We assessed key biochemical properties of the purified His-HydABC including the temperature and $\mathrm{pH}$ profile as well as substrate affinities. To ensure an ideal reflection of the physiological conditions, we exclusively used the $\mathrm{NADP}^{+}$-dependent $\mathrm{H}_{2}$ :Fd oxidoreductase assay. HisHyd $A B C$ was active at temperatures ranging from 22 to $85^{\circ} \mathrm{C}$ with a maximal activity of $26.8 \pm 2.9 \mathrm{U} / \mathrm{mg}$ at the optimal growth temperature of $T$. kivui $\left(66{ }^{\circ} \mathrm{C}\right)$ (Fig. S7A). At mesophilic conditions, His-HydABC activity was decreased by $86 \%$ at $22{ }^{\circ} \mathrm{C}$ and by $58 \%$ at $40{ }^{\circ} \mathrm{C}$. At $85{ }^{\circ} \mathrm{C}$, the activity decreased by $50 \%$. The $\mathrm{pH}$ range was relatively narrow with only $22 \%$ and $55 \%$ activity at $\mathrm{pH} 6$ and 10 and an optimal activity of $19.3 \pm 2.4 \mathrm{U} / \mathrm{mg}$ at $\mathrm{pH} 8$ (Fig. S7B). At pH 6, the activity was decreased by $78 \%$ and completely abolished at $\mathrm{pH} 5$.

Next, we assessed the $\mathrm{K}_{\mathrm{m}}$ values for all reaction partners of His-HydABC. The dependence of the $\mathrm{NADP}^{+}$-dependent $\mathrm{H}_{2}: \mathrm{Fd}$ oxidoreductase reaction on $\mathrm{H}_{2}, \mathrm{Fd}, \mathrm{NADP}^{+}$and FMN was hyperbolic with saturation at $160 \mu \mathrm{M} \mathrm{H}_{2}$ (soluble in water), $30 \mu \mathrm{M} \mathrm{Fd}, 0.2 \mathrm{mM} \mathrm{NADP}^{+}$and $2 \mu \mathrm{M} \mathrm{FMN}$, respectively (Fig. S8). The $\mathrm{Km}$ values of His-HydABC for $\mathrm{H}_{2}$, $\mathrm{Fd}, \mathrm{NADP}^{+}$and FMN were $27.5 \pm 4.5 \mu \mathrm{M}, 13.6 \pm 3.3 \mu \mathrm{M}$, $48.8 \pm 10.6 \mu \mathrm{M}$ and $0.3 \pm 0.8 \mu \mathrm{M}$, respectively (Fig. S8). Unsurprisingly, the absence of $\mathrm{H}_{2}, \mathrm{Fd}_{\text {or }} \mathrm{NADP}^{+}$led to a complete loss of activity.

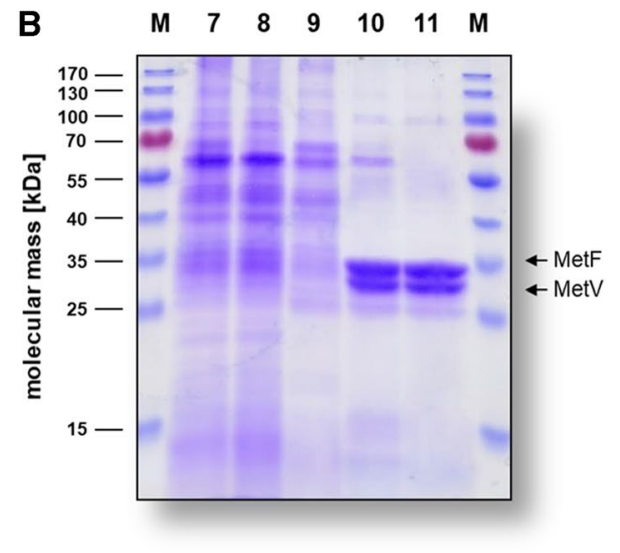

Blue G250. $10 \mu \mathrm{g}$ of protein was applied to each lane. M, prestained page ruler; lane 1 and 7, CFE; lane 2 and 8, flow through; lane 3 and 9 , wash fraction; lane 4 and 10 , pooled $\mathrm{Ni}^{2+}$-NTA elution fractions; lane 5 and 11 , pooled size exclusion fractions

\section{Purification of the MTHFR}

One of the biggest current uncertainties in the bioenergetics of acetogenic microorganisms is the energetics of the MTHFR reaction. The redox potential of the methylene-/ methyl-THF couple of $-200 \mathrm{mV}$ (Wohlfarth et al. 1990) does not allow a direct reduction of $\mathrm{NAD}^{+}$or $\mathrm{NADP}^{+}$. One solution to this problem is electron bifurcation: Cooxidation of reduced Fd by a possible electron-bifurcating MTHFR could solve the problem. This potential complex would then transfer electrons from NADH/NADPH to methyleneTHF and an additional, unidentified electron acceptor in the reductive path (Mock et al. 2014). Whether or not the MTHFR uses electron bifurcation and if so, what the second electron acceptor might be, still has to be elucidated. The picture is complicated by the fact that four different types of MTHFR's with different subunit compositions are found in acetogens. Some definitely do not bifurcate, others maybe (Öppinger et al. 2021). Therefore, we decided to purify and charcterize the MTHFR of T. kivui.

In most acetogens, the core subunits of MTHFR are MetF and MetV (Clark and Ljungdahl 1984; Mock et al. 2014; Bertsch et al. 2015; Jeong et al. 2015; Visser et al. 2016; Öppinger et al. 2021). First inspection of genomic data of T. kivui had indicated the presence of metF (TKV_c19880) and metV (TKV_c19890) (Hess et al. 2014). No $h d r$ and $m v h D$ genes, as described for M. thermoacetica (Mock et al. 2014) or Sporomusa ovata (Visser et al. 2016) or a rnfC2-like gene, which was discribed for the NADH-dependent MTHFR of A. woodii (Bertsch et al. 2015), are present in the genome of T. kivui (Hess et al. 2014). To purify MetFV, $m e t F V$ was cloned together with a DNA sequence coding for a $10 \times$ His-tag 


\section{A}
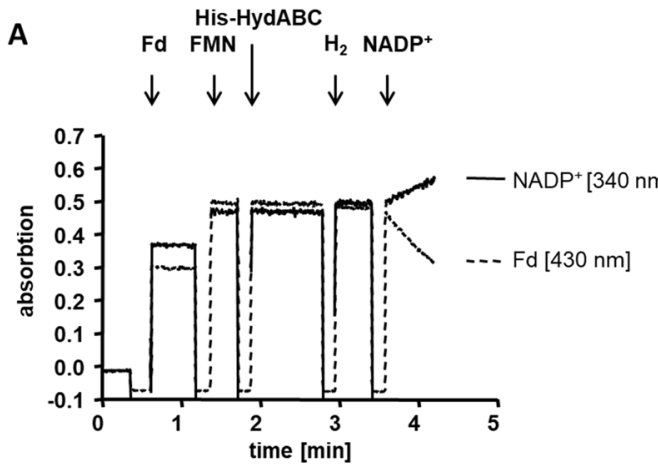

C

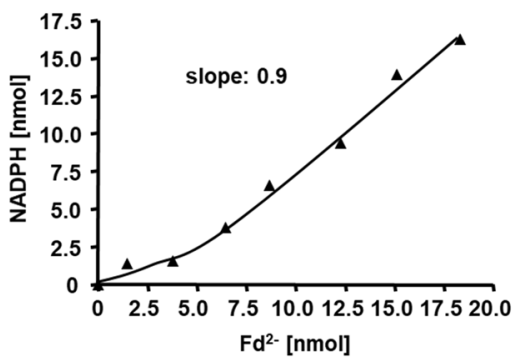

Fig. 2 Electron-bifurcating activity of the purified His-HydABC complex. Simultaneous hydrogen-dependent reduction of $\mathrm{Fd}$ and $\mathrm{NADP}^{+}$(A) was measured in $1.8-\mathrm{ml}$ anoxic cuvettes containing an overall liquid volume of $1 \mathrm{ml}$ under a $100 \% \mathrm{H}_{2}$ atmosphere $\left(2 \times 10^{5} \mathrm{~Pa}\right)$ at $66^{\circ} \mathrm{C}$. The assay contained $10 \mu \mathrm{g}$ His-HydABC, $5 \mu \mathrm{M}$ FMN and $30 \mu \mathrm{M}$ Fd served as electron acceptor in buffer D (50 mM EPPS, $10 \mathrm{mM} \mathrm{NaCl}, \mathrm{pH} 8$ ). The reaction was started by addition of $4 \mathrm{mM} \mathrm{NADP}^{+}$. Reduction of $\mathrm{NADP}^{+}$(continuous line, monitored at $340 \mathrm{~nm}$ ) and reduction of $\mathrm{Fd}$ (dashed line, monitored at $430 \mathrm{~nm}$ ) were monitored simultaneously. Hydrogen evolution from NADPH and $\mathrm{Fd}^{2-}(\mathbf{B})$ was measured via gas chromatography. The assay contained buffer D, $20 \mu \mathrm{g}$ His-HydABC, $30 \mu \mathrm{M}$ Fd, $5 \mu \mathrm{M}$ FMN and $10 \mathrm{mM}$ NADPH (ם). To reduce Fd (isolated from C. pasteurianum)

into $p M U 131$ (Fig. S5E-H) and transformed into $T$. kivui (Fig. S1C, D). The His-tagged MetFV was purified from the CFE of glucose-grown cells to apparent homogeneity by $\mathrm{Ni}^{2+}$-NTA-sepharose followed by size exclusion chromatography on Superdex 200. Using this procedure, the enzyme was purified 282-fold to apparent homogeneity with an average specific $\mathrm{MV}^{2-}$ :methylene-THF oxidoreductase activity of $593.6 \pm 161.5 \mathrm{U} / \mathrm{mg}$ and a yield of $0.4 \mathrm{mg}$ (per $2 \mathrm{~g}$ wet cells) (Table 5). Analyses of the purified His-MetFV separated on a $12 \%$ SDS-polyacrylamide gel revealed two proteins with apparent molecular masses of $\approx 33$ and $\approx 28 \mathrm{kDa}$ (Fig. 1B). These molecular masses correspond well with the expected sizes for MetV (23.5 kDa) and MetF (31.5 kDa) of T. kivui. Analytical size
B

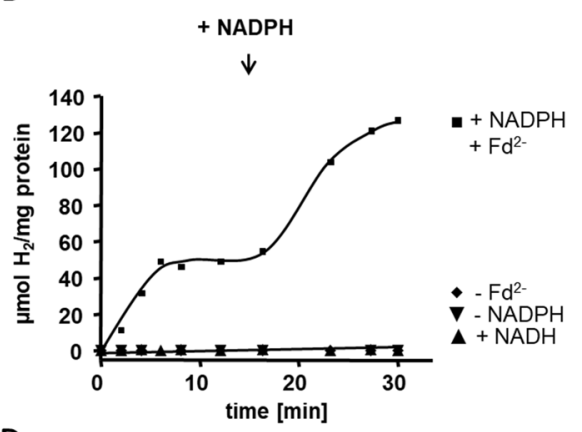

D

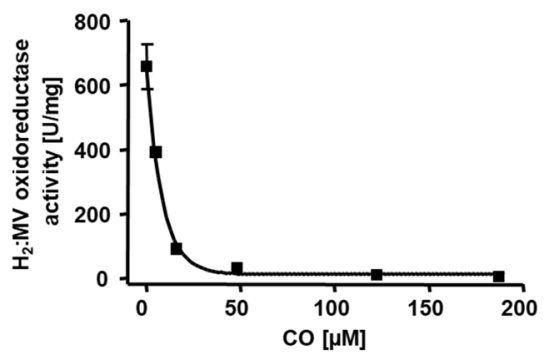

the assay additionally contained $5 \mu \mathrm{g}$ PFOR (isolated from $T$. kivui), $400 \mu \mathrm{M} \mathrm{CoA}$ and $100 \mu \mathrm{M}$ TPP. The reaction was started with 10 $\mathrm{mM}$ pyruvate. After $18 \mathrm{~min}$ additional $10 \mathrm{mM} \mathrm{NADPH}$ was added as indicated. In the controls either Fd $(\boldsymbol{)})$ or NADPH $(\boldsymbol{\nabla})$ was omitted or NADPH was replaced by NADH $(\boldsymbol{\Delta})$. Stoichiometry of $\mathrm{Fd}$ and $\mathrm{NADP}^{+}$reduction was calculated from the absorbance difference in (A). To calculate the ratio the amount of reduced $\mathrm{NADP}^{+}$is plotted against the amount of reduced $\mathrm{Fd}(\mathbf{C})$. CO inhibition experiments were performed with different $\mathrm{CO}$ concentrations in the assay (D). The assay contained 5-10 $\mu \mathrm{g}$ His-HydABC, $\mathrm{H}_{2}$ in the atmosphere $\left(1 \times 10^{5} \mathrm{~Pa}\right)$ and $10 \mathrm{mM} \mathrm{MV}$ in buffer D. The specific $\mathrm{H}_{2}: \mathrm{MV}$ oxidoreductase activity was ploted against the $\mathrm{CO}$ concentration

exclusion chromatography revealed a molecular mass of $174 \mathrm{kDa}$ for the purified complex, which is consistent with three MetFV heterodimers. We measured $7.2 \pm 0.4 \mathrm{~mol}$ of iron/mol of protein, which matches the prediction that MetFV contains two [4Fe-4S] cluster. From bioinformatic analyses, MetFV should contain one flavin, but the nature of the flavin remained to be established. After precipitation of the purified complex and subsequent separation of the flavin-containing supernatant by thin-layer chromatography (TLC), FMN could be detected (Fig. S6B).

Next, we assessed key biochemical properties of the purified His-MetFV including the temperature and $\mathrm{pH}$ profile. Therefore, we used the $\mathrm{MV}^{2-}$ :methylene-THF oxidoreductase assay. His-MetFV was active at temperatures ranging 
Table 4 Reactions catalyzed by purified His-HydABC and HisMetFV from T. kivui

\begin{tabular}{|c|c|c|}
\hline Enzyme & Substrates & Specific activity [U/mg] \\
\hline \multirow{8}{*}{$\begin{array}{l}\text { Bifurcating hydrogenase } \\
\text { (HydABC) }\end{array}$} & $\mathrm{H}_{2}+\mathrm{NADP}^{+}+\mathbf{F d}$ & $20.8 \pm 2.5$ \\
\hline & $\mathrm{H}_{2}+\mathrm{NAD}^{+}+\mathbf{F d}$ & $<0.01$ \\
\hline & $\mathrm{H}_{2}+\mathbf{F d}$ & $<0.003$ \\
\hline & $\mathrm{H}_{2}+\mathbf{N A D P}^{+}$ & $<0.005$ \\
\hline & $\mathrm{H}_{2}+\mathbf{N A D}^{+}$ & $<0.003$ \\
\hline & $\mathrm{H}_{2}+\mathbf{M V}$ & $7596.0 \pm 2370.3$ \\
\hline & $\mathrm{NADPH}+{ }^{\%} \mathrm{Fd}^{2-}+\mathrm{H}^{+} \rightarrow \mathbf{H}_{2}$ & $9.3 \pm 2.0$ \\
\hline & $\mathrm{NADH}+{ }^{\%} \mathrm{Fd}^{2-}+\mathrm{H}^{+} \rightarrow \mathbf{H}_{2}$ & $<0.002$ \\
\hline \multirow{9}{*}{$\begin{array}{l}\text { Methylene-THF reductase } \\
\text { (MetFV) }\end{array}$} & Methylene-THF + NADPH & $<0.002$ \\
\hline & Methylene-THF+NADH & $<0.001$ \\
\hline & Methylene-THF + NADH + Fd & $<0.003$ \\
\hline & Methylene-THF + NADPH + Fd & $<0.002$ \\
\hline & Methylene-THF + $\mathbf{M V}^{2-}$ & $891.8 \pm 96.5$ \\
\hline & Methylene-THF $+{ }^{\%} \mathrm{Fd}^{2-} \rightarrow$ methyl-THF & $0.4 \pm 0.04$ \\
\hline & Methyl-THF + BV & $31.2 \pm 5.7$ \\
\hline & $\mathrm{NADH}+\mathbf{B V}$ & $0.2 \pm 0.04$ \\
\hline & $\mathrm{NADPH}+\mathbf{B V}$ & $0.2 \pm 0.04$ \\
\hline
\end{tabular}

Substrates or products whose reduction, oxidation, or formation were monitored are presented in bold. The activities were determined at $66^{\circ} \mathrm{C}$. One unit (U) equals $2 \mu \mathrm{mol}$ of electrons transferred per min. All measurements were performed in biological replicates. For more details see Materials and methods

$\mathrm{Fd}$, ferredoxin (isolated from C. pasteurianum); MV, methyl viologen; $\mathrm{BV}$, benzyl viologen; THF, tetrahydrofolate

${ }^{\%} \mathrm{Fd}^{2-}$-regenerating system (Fd, TPP, CoA, pyruvate, PFOR (Katsyv et al. 2021))
Table 5 Purification of His-MetFV from T. kivui

\begin{tabular}{lllll}
\hline $\begin{array}{l}\text { Purification } \\
\text { step }\end{array}$ & Protein [mg] & $\begin{array}{l}\text { MetFV } \\
\text { activity } \\
{[\mathrm{U} / \mathrm{mg}]}\end{array}$ & $\begin{array}{l}\text { Purification } \\
{[\text {-fold] }}\end{array}$ & Yield [\%] \\
\hline CFE & 356.2 & 2.1 & 1 & 100 \\
$\mathrm{Ni}^{2+}$-NTA & 1.7 & 532.5 & 253.6 & 0.5 \\
Superdex 200 & 0.4 & 593.6 & 282.6 & 0.2 \\
\hline
\end{tabular}

${ }^{+}$MetFV activity was measured with reduced MV as electron donor and methylene-THF as electron acceptor

from 22 to $85{ }^{\circ} \mathrm{C}$ with a maximal activity of $481.2 \pm 34.9$ $\mathrm{U} / \mathrm{mg}$ at the optimal growth temperature of T. kivui $\left(66^{\circ} \mathrm{C}\right)$ (Fig. S9A). At mesophilic conditions, His-MetFV activity was decreased by $88 \%$ at $22{ }^{\circ} \mathrm{C}$ and by $56 \%$ at $40{ }^{\circ} \mathrm{C}$. At 75 and $85{ }^{\circ} \mathrm{C}$, the activity decreased only by $9 \%$. The $\mathrm{pH}$ range was relatively narrow with $89 \%$ and $67 \%$ activity at $\mathrm{pH} 6$ and 8 and an optimal activity of $258.7 \pm 43.4 \mathrm{U} / \mathrm{mg}$ at pH 7 (Fig. S9B). In contrast, the activity at pH 5 and 9 was almost abolished.
The purified MetFV complex catalyzed the reduction of methylene-THF with reduced MV at a specific activity of $593.6 \pm 161.5 \mathrm{U} / \mathrm{mg}$ (Fig. 3A). The complex did not catalyze the oxidation of NADH or NADPH in the presence of methylene-THF (Fig. S10A, B). NADH/NADPH:BV oxidoreductase activity was weak with only $0.2 \pm 0.04 \mathrm{U} / \mathrm{mg}$ (Fig. S11). We also tested whether Fd (isolated from C. pasteurianum) was reduced by NADH or NADPH in the presence of methylene-THF, which was not the case (Fig. S12A, B). Besides reduced $\mathrm{MV}$, we could identify reduced $\mathrm{Fd}$ as possible electron donor for the reduction of methylene-THF to methylTHF in vitro. In the $\mathrm{Fd}^{2-}$ :methylene-THF oxidoreductase assay, Fd was kept in a reduced state by the PFOR, isolated from T. kivui (Katsyv et al. 2021). From the production of methyl-THF over time, a specific activity of $0.4 \pm 0.04 \mathrm{U} / \mathrm{mg}$ was calculated (Fig. 3B). The reverse reaction, oxidation of methyl-THF was not coupled to $\mathrm{NAD}^{+}, \mathrm{NADP}^{+}$or Fd reduction (Fig. S13-C), but only to BV reduction $(115.0 \pm 42.2 \mathrm{U} /$ mg) (Fig. 3C). Therefore, like in any other purified MetFVtype MTHFRs, the physiological electron carrier involved 

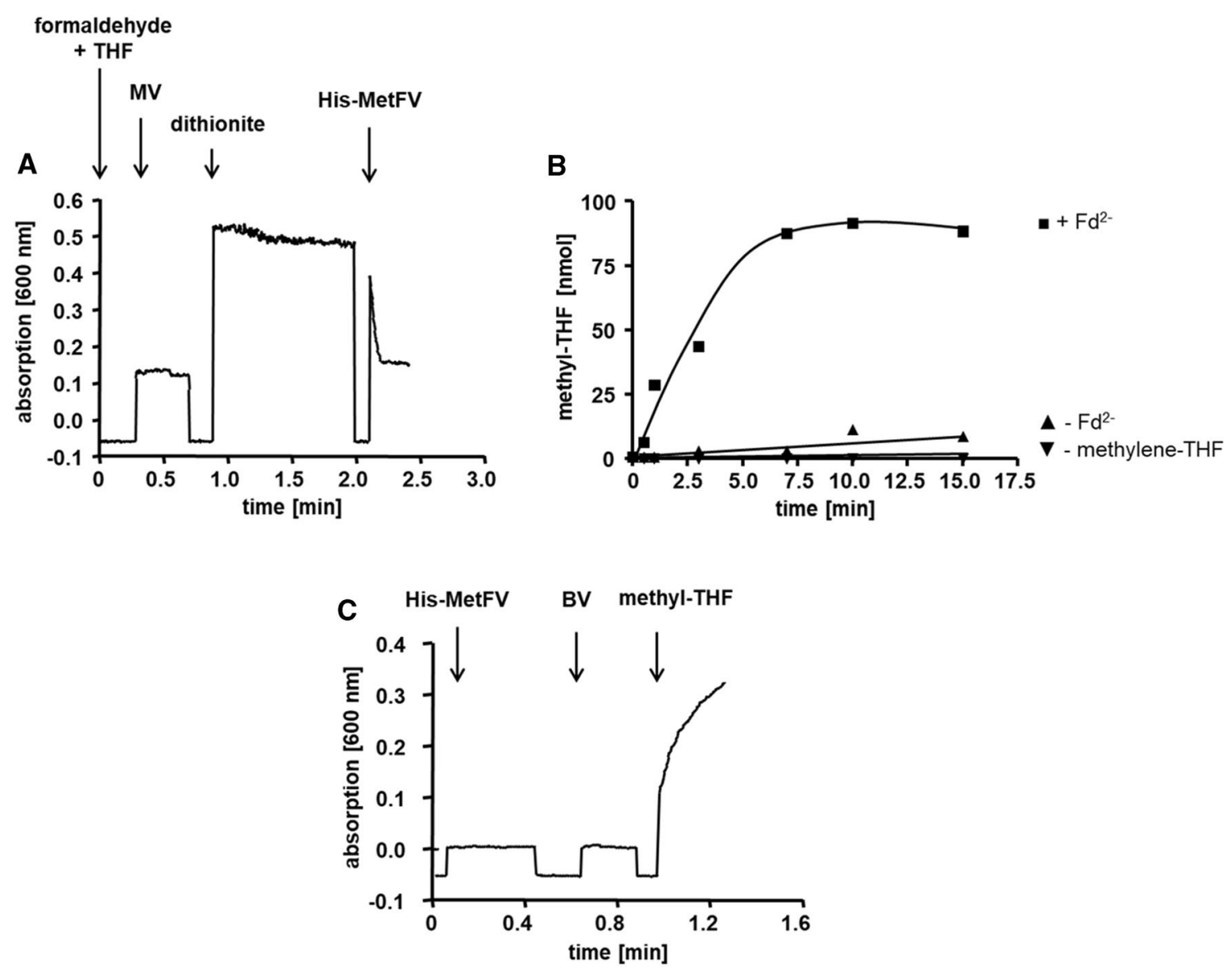

Fig. 3 Oxidoreductase activity of the purified His-MetFV. $\mathrm{MV}^{2-}$ :methylene-THF (A), $\mathrm{Fd}^{2-}$ :methylene-THF (B) and methylTHF:BV oxidoreductase activity $(\mathbf{C})$ was measured in $1.8-\mathrm{ml}$ anoxic cuvettes containing an overall liquid volume of $1 \mathrm{ml}$ under a $100 \%$ $\mathrm{N}_{2}$ atmosphere $\left(1 \times 10^{5} \mathrm{~Pa}\right)$ at $66^{\circ} \mathrm{C} . \mathrm{MV}^{2-}$ :methylene-THF oxidoreductase assay contained $0.5 \mathrm{mM}$ THF, $1.5 \mathrm{mM}$ formaldehyde, $10 \mathrm{mM}$ $\mathrm{MV}$ and $5 \mathrm{mM}$ sodium dithionite in buffer $\mathrm{F}(50 \mathrm{mM} \mathrm{KP}, 20 \mathrm{mM}$ ascorbate, $\mathrm{pH} 7$ ). The reaction was started by addition of $5 \mu \mathrm{g}$ HisMetFV. $\mathrm{Fd}^{2-}$ :methylene-THF oxidoreductase activity assay contained $30 \mu \mathrm{g}$ His-MetFV, $30 \mu \mathrm{M}$ Fd, $0.5 \mathrm{mM}$ THF and $1.5 \mathrm{mM}$ formalde-

in methylene-THF reduction remains enigmatic. All activities of His-MetFV observed in this work are summarized in Table 4.

Recently, the MetFV-type MTHFR of C. ljungdahlii (Öppinger et al. 2021) and Eubacterium callanderi (Dietrich et al. 2021), was shown to exhibit a $\mathrm{Fd}^{2-}$ :methylene-THF oxidoreductase activity in vitro as well. Fd-dependent methylene-THF reduction by MetFV would lead to a negative ATP yield during acetogenesis from $\mathrm{H}_{2}+\mathrm{CO}_{2}$, therefore, hyde in buffer $\mathrm{F}(\mathbf{C})$. To reduce $\mathrm{Fd}$ (isolated from C. pasteurianum) the assay additionly contained $5 \mu \mathrm{g}$ PFOR (isolated from $T$. kivui), $400 \mu \mathrm{M} \mathrm{CoA}$ and $100 \mu \mathrm{M}$ TPP. The reaction was started by addition of $10 \mathrm{mM}$ pyruvate $(\boldsymbol{\square})$. In the controls either $\mathrm{Fd}(\boldsymbol{\Delta})$ or methyleneTHF ( $)$ was omitted. After $0.5,1,3,7,10$ and 15 min the amount of produced methyl-THF was meassured via HPLC, respectively (Dietrich et al. 2021). The methyl-THF:BV oxidoreductase activity assay contained $30 \mu \mathrm{g}$ purified His-MetFV and $1 \mathrm{mM}$ methyl-THF in buffer F. The reaction was started by addition of $10 \mathrm{mM}$ BV. Oxidation of MV or reduction of BV was measured at $600 \mathrm{~nm}$, respectively

reduced Fd cannot be the physiological electron donor for C. ljungdahlii and Eubacterium callanderi. This is also true for the bioenergetics of T. kivui. Therefore, it was hypothesized that methylene-THF reduction is directly coupled to a respiratory complex (Öppinger et al. 2021). In case of T. kivui, a membrane-coupled Ech-MetFV complex was assumed (Öppinger et al. 2021). Please note that T. kivui has two gene clusters encoding Ech complexes with slightly different subunit compositions (Hess et al. 2014). The exact 


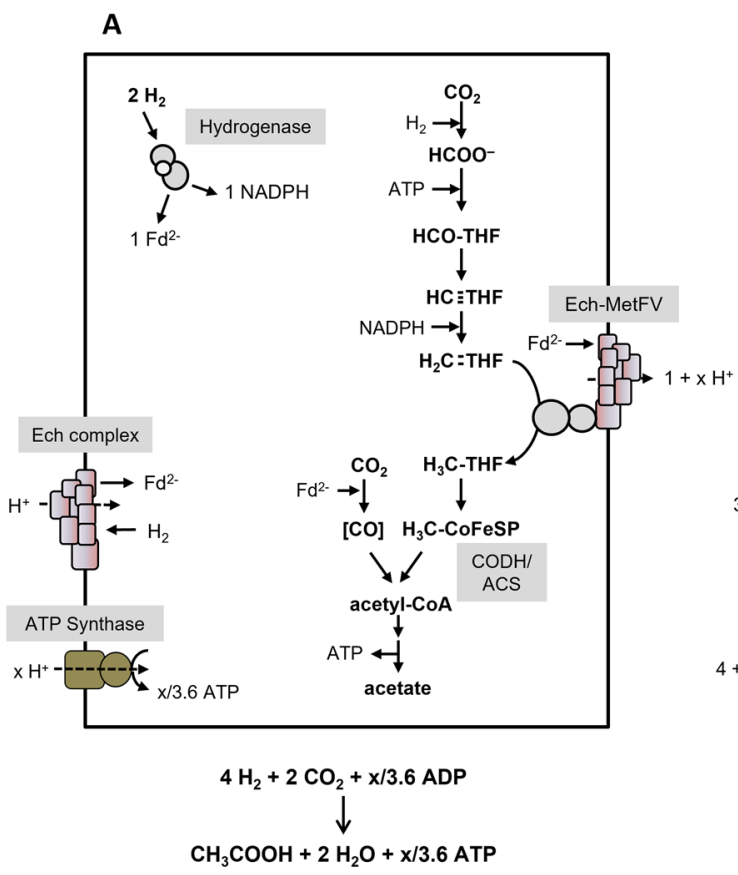

Fig. 4 Bioenergetics of acetate formation from $\mathrm{H}_{2}+\mathrm{CO}_{2}$ or $\mathrm{CO}$ in $T$. kivui. Acetate is formed from $\mathrm{H}_{2}+\mathrm{CO}_{2}(\mathbf{A})$ or $\mathrm{CO}(\mathbf{B})$. The reducing equivalents in the WLP are provided by an $\mathrm{H}_{2}$-oxidizing, electronbifurcating hydrogenase which reduces $\mathrm{Fd}$ and $\mathrm{NADP}^{+}$. We assume methylene-THF reduction by a membrane-coupled Ech-MetFV complex, which pumps $1+\mathrm{x} \mathrm{H}^{+} / 2 \mathrm{e}^{-}$across the membrane (Öppinger et al. 2021). Please note that T. kivui has two gene clusters encoding Ech complexes with slightly different subunit compositions. Ech-MetFV complex (A) and Ech complex (B) builds up a $\mathrm{H}^{+}$gra-

thermodynamics for the Ech complex of T. kivui remained to be established, nevertheless it is plausible to assume a $\mathrm{H}^{+} / 2 \mathrm{e}^{-}$stoichiometry for the $\mathrm{Fd}^{2-}: \mathrm{H}^{+}$oxidoreductase of 1 to calculate ATP yields during growth. However, the free energy change is drastically increased, if methylene-THF serves as final electron acceptor $\left(\Delta G_{0}{ }^{\prime}=-48.3 \mathrm{~kJ} / \mathrm{mol}\right.$, compared to $\Delta G_{0}{ }^{\prime}=-6.9 \mathrm{~kJ} / \mathrm{mol}$, based on a redox potential of $-414 \mathrm{mV}$ for $2 \mathrm{H}^{+} / \mathrm{H}_{2}$ ). Therefore, we will indicate " $1+\mathrm{x}$ " per methylene-THF reduced in the Ech-MetFV complex catalyzed reaction. For the ATP synthase, a $\mathrm{H}^{+} /$ATP stoichiometry of 3.6 is assumed (based on a number of $11 \mathrm{c}$ subunits in the $c$-ring of the ATP synthase of Clostridium paradoxum (Ferguson et al. 2006; Meier et al. 2006). Then, acetogenesis from $\mathrm{H}_{2}+\mathrm{CO}_{2}$ is coupled to the synthesis of $\mathrm{x} / 3.6 \mathrm{~mol} \mathrm{ATP} /$ mol acetate (Fig. 4A), whereas acetogenesis from $\mathrm{CO}$ yields $1.1+(\mathrm{x} / 3.6) \mathrm{mol} \mathrm{ATP} / \mathrm{mol}$ acetate (Fig. 4B). This model is also applicable to acetogenesis from other substrates, like glucose (Fig. 5A) or mannitol (Fig. 5B) for T. kivui. With glucose, the ATP yield is $0.87+(\mathrm{x} / 10.8) \mathrm{ATP} / \mathrm{mol}$ acetate. For mannitol, the value is lower with $0.22+(\mathrm{x} / 46.8)$ ATP/ mol acetate.
B

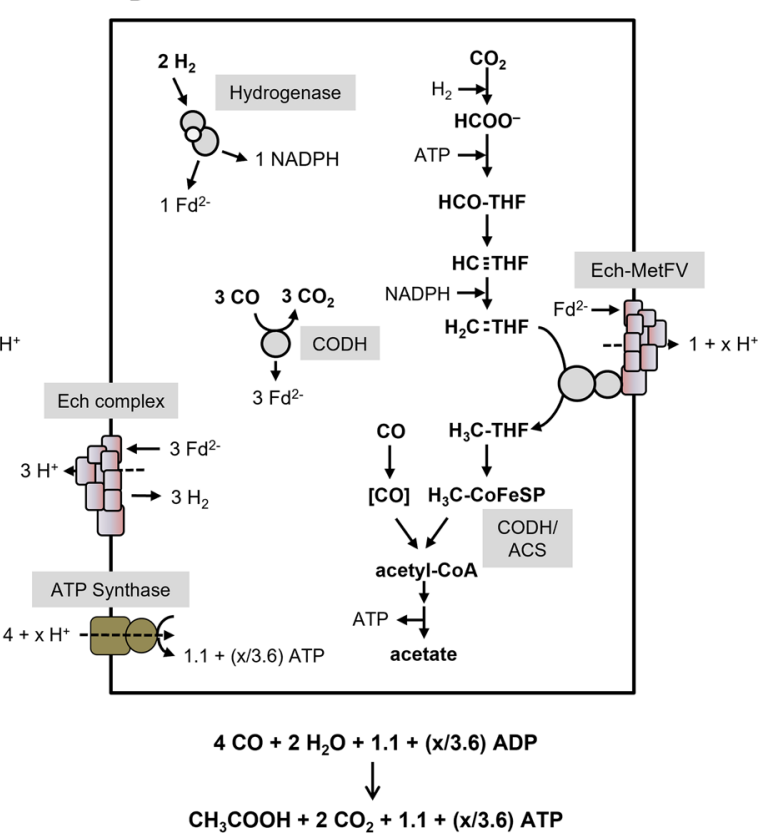

dient across the cytoplasmatic membrane. This gradient drives ATP synthesis via the $\mathrm{H}^{+}$-dependent ATP synthase. In total, $\mathrm{x} / 3.6$ ATP or $1.1+(\mathrm{x} / 3.6)$ ATP can be synthesized per acetate produced from $\mathrm{H}_{2}+\mathrm{CO}_{2}$ or CO. Adapted from Öppinger et al. (2021). Assumed stoichiometries: $\mathrm{H}^{+} / \mathrm{ATP}=3.6$ (ATP synthase), $1 \mathrm{H}^{+} / 2 \mathrm{e}^{-}($Ech) and $1+\mathrm{x}$ $\mathrm{H}^{+} / 2 \mathrm{e}^{-}$(Ech-MetVF). ATP gain might be enhanced by $\mathrm{x} / 3.6$ ATP. CODH/ACS, CO dehydrogenase/acetyl coenzyme A synthase; THF, tetrahydrofolic acid; Ech, Energy-converting Hydrogenase

\section{Conclusion}

With the data presented in this report, we have now a much better understanding of the biochemistry and metabolism of different carbon and energy sources in T. kivui. We have identified for all but one oxidoreductases the electron carriers. The MetFV-type MTHFR only uses reduced Fd as electron donor, but not NADH or NADPH. Reduced Fd can not be the direct physiological electron donor, but it is hypothesized that the MTHFR is hooked up to the Ech complex. The actual amount of ions translocated is unknown but must be bigger than 1. With $\mathrm{H}_{2}+\mathrm{CO}_{2}$ as substrate $\mathrm{x} / 3.6 \mathrm{~mol} \mathrm{ATP} / \mathrm{mol}$ acetate are formed, whereas acetogenesis from $\mathrm{CO}$ yield $1.1+(\mathrm{x} / 3.6) \mathrm{mol}$ ATP/mol acetate. During sugar fermentation, hydrogen is produced by the electron-bifurcating hydrogenase. The NADPH is provided by the Nfn complex. With glucose the ATP yield is $0.87+(\mathrm{x} / 10.8) \mathrm{ATP} / \mathrm{mol}$ acetate and with mannitol 0.22 $+(\mathrm{x} / 46.8) \mathrm{ATP} / \mathrm{mol}$ acetate. 


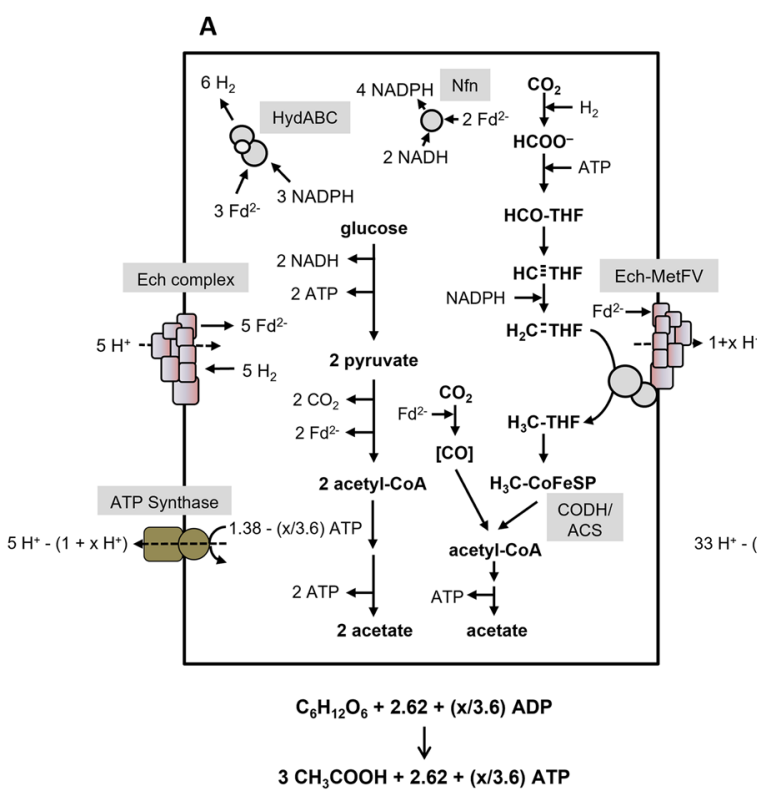

Fig. 5 Bioenergetics of acetate formation from glucose or mannitol in T. kivui. Glucose (A) or mannitol (B) are converted via glycolysis to acetate. Produced and supplied $\mathrm{CO}_{2}$ and reducing equivalents are further utilized via the WLP, giving rise for an additional acetate. $\mathrm{Fd}^{2-}$ is oxidized by the bifurcating hydrogenase and the Nfn complex to produce $\mathrm{H}_{2}$ and to reduce $\mathrm{NADP}^{+}$, respectively. Hydrogen is further oxidized to reduce $\mathrm{CO}_{2}$ by the HDCR. Fd is reduced with $\mathrm{H}_{2}$ as electron donor by the Ech complex, fueled by the $\mathrm{H}^{+}$gradient formed by the $\mathrm{H}^{+}$-dependent ATPase. We assume methylene-THF reduction by a membrane-coupled Ech-MetFV complex, which pumps

Supplementary Information The online version contains supplementary material available at https://doi.org/10.1007/s00792-021-01247-8.

Acknowledgements We are grateful to the Deutsche Forschungsgemeinschaft (DFG) and the Bundesministerium für Bildung und Forschung (BMBF; ThermoSynCon) for financial support. S.J. holds a fellowship from the DAAD (German Academic Exchange Service).

Author contributions VM, AK and MB designed the experiments. AK performed the experiments. SJ measured the methylene-THF dehydrogenase activity. VM and AK wrote the paper.

Funding Open Access funding enabled and organized by Projekt DEAL.

\section{Declarations}

Conflict of interest The authors declare no conflict of interest.

Open Access This article is licensed under a Creative Commons Attribution 4.0 International License, which permits use, sharing, adaptation, distribution and reproduction in any medium or format, as long as you give appropriate credit to the original author(s) and the source, provide a link to the Creative Commons licence, and indicate if changes were made. The images or other third party material in this article are included in the article's Creative Commons licence, unless indicated otherwise in a credit line to the material. If material is not included in the article's Creative Commons licence and your intended use is not

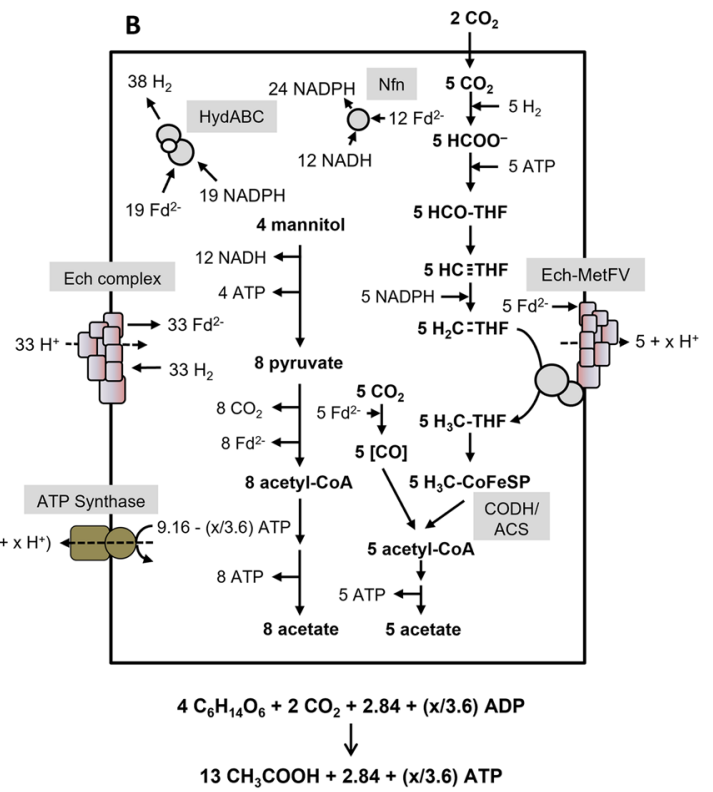

$1+\mathrm{x} \mathrm{H}^{+} / 2 \mathrm{e}^{-}$across the membrane (Öppinger et al. 2021). Please note that $T$. kivui has two gene clusters encoding Ech complexes with slightly different subunit compositions. In total, $0.87+(\mathrm{x} / 10.8)$ ATP or $0.22+(\mathrm{x} / 46.8)$ ATP can be synthesized per acetate produced from glucose or mannitol. Assumed stoichiometries: $\mathrm{H}^{+} / \mathrm{ATP}=3.6$ (ATP synthase), $1 \mathrm{H}^{+} / 2 \mathrm{e}^{-}$(Ech) and $1+\mathrm{x} \mathrm{H}^{+} / 2 \mathrm{e}^{-}$(Ech-MetVF). ATP gain might be enhanced by x/3.6 ATP. CODH/ACS, CO dehydrogenase/ acetyl coenzyme A synthase; THF, tetrahydrofolic acid; Nfn, transhydrogenase; Ech, Energy-converting Hydrogenase; HDCR, hydrogendependent $\mathrm{CO}_{2}$ reductase

permitted by statutory regulation or exceeds the permitted use, you will need to obtain permission directly from the copyright holder. To view a copy of this licence, visit http://creativecommons.org/licenses/by/4.0/.

\section{References}

Basen M, Müller V (2017) "Hot" acetogenesis. Extremophiles 21:1526. https://doi.org/10.1007/s00792-016-0873-3

Basen M, Geiger I, Henke L, Müller V (2018) A genetic system for the thermophilic acetogenic bacterium Thermoanaerobacter kivui. Appl Environ Microbiol 84:e02210-02217. https://doi.org/10. 1128/AEM.02210-17

Bertsch J, Parthasarathy A, Buckel W, Müller V (2013) An electronbifurcating caffeyl-CoA reductase. J Biol Chem 288:1130411311. https://doi.org/10.1074/jbc.M112.444919

Bertsch J, Öppinger C, Hess V, Langer JD, Müller V (2015) Heterotrimeric NADH-oxidizing methylenetetrahydrofolate reductase from the acetogenic bacterium Acetobacterium woodii. J Bacteriol 197:1681-1689. https://doi.org/10.1128/JB.00048-15

Biegel E, Müller V (2010) Bacterial $\mathrm{Na}^{+}$-translocating ferredoxin:NAD ${ }^{+}$oxidoreductase. Proc Natl Acad Sci USA 107:18138-18142. https://doi.org/10.1073/pnas.1010318107

Bradford MM (1976) A rapid and sensitive method for the quantification of microgram quantities of protein utilizing the principle of proteine-dye-binding. Anal Biochem 72:248-254. https://doi. org/10.1016/0003-2697(76)90527-3 
Bryant MP (1972) Commentary on the Hungate technique for culture of anaerobic bacteria. Am J Clin Nutr 25:1324-1328. https:// doi.org/10.1093/ajcn/25.12.1324

Clark JE, Ljungdahl LG (1984) Purification and properties of 5,10-methylenetetrahydrofolate reductase, an iron-sulfur flavoprotein from Clostridium formicoaceticum. J Biol Chem 259:10845-10849. https://doi.org/10.1016/S0021-9258(18) 90590-9

Daniell J, Köpke M, Simpson SD (2012) Commercial biomass syngas fermentation. Energies 5:5372-5417. https://doi.org/10. 3390/en5125372

Dietrich HM, Kremp F, Öppinger C, Ribaric L, Müller V (2021) Biochemistry of methanol-dependent acetogenesis in Eubacterium callanderi KIST612. Environ Microbiol. https://doi.org/ $10.1111 / 1462-2920.15643$ (in press)

Drake HL, Gößner AS, Daniel SL (2008) Old acetogens, new light. Ann N Y Acad Sci 1125:100-128. https://doi.org/10.1196/ annals. 1419.016

Fairhurst AS, King HK, Sewell CE (1956) Studies in amino acid biogenesis: the synthesis of alanine from pyruvate and ammonia. J Gen Microbiol 15:106-120. https://doi.org/10.1099/00221 287-15-1-106

Ferguson SA, Keis S, Cook GM (2006) Biochemical and molecular characterization of a $\mathrm{Na}^{+}$-translocating $\mathrm{F}_{1} \mathrm{~F}_{\mathrm{O}}$-ATPase from the thermoalkaliphilic bacterium Clostridium paradoxum. J Bacteriol 188:5045-5054. https://doi.org/10.1128/JB.00128-06

Fish WW (1988) Rapid colorimetric micromethod for the quantitation of complexed iron in biological samples. Methods Enzymol 158:357-364. https://doi.org/10.1016/0076-6879(88)58067-9

Hess V, Schuchmann K, Müller V (2013) The ferredoxin:NAD ${ }^{+}$oxidoreductase (Rnf) from the acetogen Acetobacterium woodii requires $\mathrm{Na}^{+}$and is reversibly coupled to the membrane potential. J Biol Chem 288:31496-31502. https://doi.org/10.1074/ jbc.M113.510255

Hess V, Poehlein A, Weghoff MC, Daniel R, Müller V (2014) A genome-guided analysis of energy conservation in the thermophilic, cytochrome-free acetogenic bacterium Thermoanaerobacter kivui. BMC Genom 15:1139. https://doi.org/10.1186/ 1471-2164-15-1139

Himes RH, Harmony JA (1973) Formyltetrahydrofolate synthetase. CRC Crit Rev Biochem 1:501-535. https://doi.org/10.3109/ 10409237309105441

Hungate RE (1969) A roll tube method for cultivation of strict anaerobes. In: Norris JR, Ribbons DW (eds) Methods in microbiology. Academic Press, New York and London, pp 117-132

Jain S, Dietrich HM, Müller V, Basen M (2020) Formate is required for growth of the thermophilic acetogenic bacterium Thermoanaerobacter kivui lacking hydrogen-dependent carbon dioxide reductase (HDCR). Front Microbiol 11:59. https://doi.org/10.3389/fmicb. 2020.00059

Jain S, Katsyv A, Basen M, Müller V (2021) The monofunctional CO dehydrogenase CooS is essential for growth of Thermoanaerobacter kivui on carbon monoxide. Extremophiles (in press)

Jeong J, Bertsch J, Hess V, Choi S, Choi IG, Chang IS, Müller V (2015) Energy conservation model based on genomic and experimental analyses of a carbon monoxide-utilizing, butyrate-forming acetogen, Eubacterium limosum KIST612. Appl Environ Microbiol 81:4782-4790. https://doi.org/10.1128/AEM.00675-15

Kallen RG, Jencks WP (1966) The mechanism of the condensation of formaldehyde with tetrahydrofolic acid. J Biol Chem 241:58515863. https://doi.org/10.1016/S0021-9258(18)96350-7

Kandler O (1983) Carbohydrate metabolism in lactic acid bacteria. Antonie Van Leeuwenhoek 49:209-224. https://doi.org/10.1007/ BF00399499
Katsyv A, Müller V (2020) Overcoming energetic barriers in acetogenic $\mathrm{C} 1$ conversion. Front Bioeng Biotechnol 8:621166. https:// doi.org/10.3389/fbioe.2020.621166

Katsyv A, Schoelmerich MC, Basen M, Müller V (2021) The pyruvate:ferredoxin oxidoreductase of the thermophilic acetogen, Thermoanaerobacter kivui. FEBS Open Bio 11:1332-1342. https://doi.org/10.1002/2211-5463.13136

Klemps R, Schoberth SM, Sahm H (1987) Production of acetic acid by Acetogenium kivui. Appl Microbiol Biotechnol 27:229-234. https://doi.org/10.1007/BF00252923

Köpke M, Simpson SD (2020) Pollution to products: recycling of "above ground" carbon by gas fermentation. Curr Opin Biotechnol 65:180-189. https://doi.org/10.1016/j.copbio.2020.02.017

Kremp F, Roth J, Müller V (2020) The Sporomusa type Nfn is a novel type of electron-bifurcating transhydrogenase that links the redox pools in acetogenic bacteria. Sci Rep 10:14872. https://doi.org/10. 1038/s41598-020-71038-2

Kuhns M, Trifunović D, Huber H, Müller V (2020) The Rnf complex is a $\mathrm{Na}^{+}$coupled respiratory enzyme in a fermenting bacterium Thermotoga Maritima. Commun Biol 3:431. https://doi.org/10. 1038/s42003-020-01158-y

Leigh JA, Mayer F, Wolfe RS (1981) Acetogenium kivui, a new thermophilic hydrogen-oxidizing, acetogenic bacterium. Arch Microbiol 129:275-280. https://doi.org/10.1007/BF00414697

Liew F, Martin ME, Tappel RC, Heijstra BD, Mihalcea C, Köpke M (2016) Gas fermentation - a flexible platform for commercial scale production of low-carbon-fuels and chemicals from waste and renewable feedstocks. Front Microbiol 11:694-722. https://doi. org/10.3389/fmicb.2016.00694

Ljungdahl LG (1986) The autotrophic pathway of acetate synthesis in acetogenic bacteria. Ann Rev Microbiol 40:415-450. https://doi. org/10.1146/annurev.mi.40.100186.002215

Meier T, Ferguson SA, Cook GM, Dimroth P, Vonck J (2006) Structural investigations of the membrane-embedded rotor ring of the F-ATPase from Clostridium paradoxum. J Bacteriol 188:77597764. https://doi.org/10.1128/JB.00934-06

Mock J, Wang S, Huang H, Kahnt J, Thauer RK (2014) Evidence for a hexaheteromeric methylenetetrahydrofolate reductase in Moorella thermoacetica. J Bacteriol 196:3303-3314. https://doi.org/10. 1128/JB.01839-14

Moon J, Jain S, Müller V, Basen M (2020) Homoacetogenic conversion of mannitol by the thermophilic acetogenic bacterium Thermoanaerobacter kivui requires external $\mathrm{CO}_{2}$. Front Microbiol 11:571736. https://doi.org/10.3389/fmicb.2020.571736

Müller V (2003) Energy conservation in acetogenic bacteria. Appl Environ Microbiol 69:6345-6353. https://doi.org/10.1128/AEM. 69.11.6345-6353.2003

Müller V (2019) New horizons in acetogenic conversion of one-carbon substrates and biological hydrogen storage. Trends Biotechnol 37:1344-1354. https://doi.org/10.1016/j.tibtech.2019.05.008

Müller V, Chowdhury NP, Basen M (2018) Electron bifurcation: a longhidden energy-coupling mechanism. Annu Rev Microbiol 72:331353. https://doi.org/10.1146/annurev-micro-090816-093440

Nagarajan H, Sahin M, Nogales J, Latif H, Lovley DR, Ebrahim A, Zengler K (2013) Characterizing acetogenic metabolism using a genome-scale metabolic reconstruction of Clostridium ljungdahlii. Microb Cell Fact 12:118-131. https://doi.org/10.1186/ 1475-2859-12-118

Öppinger C, Kremp F, Müller V (2021) Is reduced ferredoxin the physiological electron donor for MetVF-type methylenetetrahydrofolate reductases in acetogenesis? A hypothesis. Int Microbiol. https:// doi.org/10.1007/s10123-021-00190-0 (in press) 
Ragsdale SW, Wood HG (1985) Acetate biosynthesis by acetogenic bacteria. Evidence that carbon monoxide dehydrogenase is the condensing enzyme that catalyzes the final steps in the synthesis. J Biol Chem 260:3970-3977. https://doi.org/10.1016/S00219258(18)89217-1

Schaupp A, Ljungdahl LG (1974) Purification and properties of acetate kinase from Clostridium thermoaceticum. Arch Microbiol 100:121-129. https://doi.org/10.1007/BF00446312

Schoelmerich MC, Müller V (2019) Energy conservation by a hydrogenase-dependent chemiosmotic mechanism in an ancient metabolic pathway. Proc Natl Acad Sci USA 116:6329-6334. https://doi.org/ 10.1073/pnas.1818580116

Schönheit P, Wäscher C, Thauer RK (1978) A rapid procedure for the purification of ferredoxin from Clostridia using polyethylenimine. FEBS Lett 89:219-222. https://doi.org/10.1016/0014-5793(78) 80221-X

Schuchmann K, Müller V (2012) A bacterial electron bifurcating hydrogenase. J Biol Chem 287:31165-31171. https://doi.org/10. 1074/jbc.M112.395038

Schuchmann K, Müller V (2014) Autotrophy at the thermodynamic limit of life: a model for energy conservation in acetogenic bacteria. Nat Rev Microbiol 12:809-821. https://doi.org/10.1038/ nrmicro3365

Schwarz FM, Müller V (2020) Whole-cell biocatalysis for hydrogen storage and syngas conversion to formate using a thermophilic acetogen. Biotechnol Biofuels 13:32. https://doi.org/10.1186/ s13068-020-1670-x

Schwarz FM, Schuchmann K, Müller V (2018) Hydrogenation of $\mathrm{CO}_{2}$ at ambient pressure catalyzed by a highly active thermostable biocatalyst. Biotechnol Biofuels 11:237. https://doi.org/10.1186/ s13068-018-1236-3

Schwarz FM, Oswald F, Müller V (2021) Acetogenic conversion of $\mathrm{H}_{2}$ and $\mathrm{CO}_{2}$ into formic acid and vice versa in a fed-batch operated stirred tank bioreactor. ACS Sustain Chem Eng 9:6810-6820. https://doi.org/10.1021/acssuschemeng.1c01062
Shaw AJ, Hogsett DA, Lynd LR (2010) Natural competence in Thermoanaerobacter and Thermoanaerobacterium species. Appl Environ Microbiol 76:4713-4719. https://doi.org/10.1128/AEM.00402-10

Thauer RK, Jungermann K, Decker K (1977) Energy conservation in chemotrophic anaerobic bacteria. Bact Rev 41:100-180. https:// doi.org/10.1128/br.41.1.100-180.1977

Visser M, Pieterse MM, Pinkse MW, Nijsse B, Verhaert PD, de Vos WM, Schaap PJ, Stams AJM (2016) Unravelling the one-carbon metabolism of the acetogen Sporomusa strain An4 by genome and proteome analysis. Environ Microbiol 18:2843-2855. https://doi. org/10.1111/1462-2920.12973

Wang S, Huang H, Kahnt J, Thauer RK (2013a) A reversible electronbifurcating ferredoxin- and $\mathrm{NAD}^{+}$-dependent $[\mathrm{FeFe}]$-hydrogenase (HydABC) in Moorella thermoacetica. J Bacteriol 195:12671275. https://doi.org/10.1128/JB.02158-12

Wang S, Huang H, Kahnt J, Müller AP, Köpke M, Thauer RK (2013b) $\mathrm{NADP}^{+}$-specific electron-bifurcating $[\mathrm{FeFe}]$-hydrogenase in a functional complex with formate dehydrogenase in Clostridium autoethanogenum grown on CO. J Bacteriol 195:4373-4386. https://doi.org/10.1128/JB.00678-13

Weghoff MC, Müller V (2016) CO metabolism in the thermophilic acetogen Thermoanaerobacter kivui. Appl Environ Microbiol 82:2312-2319. https://doi.org/10.1128/AEM.00122-16

Wohlfarth G, Geerligs G, Diekert G (1990) Purification and properties of a NADH-dependent 5,10-methylenetetrahydrofolate reductase from Peptostreptococcus productus. Eur J Biochem 192:411-417. https://doi.org/10.1111/j.1432-1033.1990.tb19242.x

Wood HG, Ragsdale SW, Pezacka E (1986) The acetyl-CoA pathway of autotrophic growth. FEMS Microbiol Rev 39:345-362. https:// doi.org/10.1111/j.1574-6968.1986.tb01865.x

Publisher's Note Springer Nature remains neutral with regard to jurisdictional claims in published maps and institutional affiliations. 